\title{
ABSTRACTS AND REVIEWS
}

\section{BACTERIOLOGY.}

\section{GeneraL.}

M. O. Robinson. An aid to more accurate colony counting. Amer. J. Pub. Health, 20, xi, 1232-3, Nov. 1930.

A specially constructed pen is used which, when pressed against the plate, records the colony electrically, thus saving the worker the fatigue of counting mentally. It is claimed that fatigue and inaccuracy are greatly diminished.

J. G. Davis

J. Y. Johnson. Cultivation of micro-organisms. B.P. 332, 235, July 11, 1930. (J. Inst. Brewing, 36, xii, 606, December 1930.)

The process described relates to the production of suitable culture media for yeast and other micro-organisms. Peat is hydrolysed by heating with acids, and the resulting liquid, after partial neutralisation, if necessary, is clarified by the addition of metallic compounds, such as sodium silicate, lime, aluminium sulphate, etc., which yield voluminous precipitates. After filtration nutrient salts are added, and the sterile liquid is inoculated with pure cultures of yeast, citromyces or other organisms.

R. LECOQ. Un milieu vitaminé de préparation simple et rapide pour la culture des microbes. (Vitamin medium of simple and rapid preparation for the cultivation of microbes.) C.R. Soc. Biol. 105, xxxiii, 636-8, December 5, 1930.

A broth suitable for the cultivation of the commonly occurring bacteria can be quickly prepared from peptone, dried malt extract and certain mineral salts. If a solid medium is required agar-agar may be added.

E. R. Hiscox

W. Kopaczewski. Conditions physico-chimiques de la vitalité microbienne. (Physical chemical conditions of microbial vitality.) Archiv f. Mikrobiol.2, ii, 187-244, April 1931.

This paper is an attempt to reduce the factors responsible for biological phenomena such as bacterial antagonism and pathogenicity to physical terms. It contains valuable data for the physical constants of media and cultures of type organisms $(p H$, surface tension, electrical conductivity, viscosity, density and organoleptic properties).

J. G. Davis

E. M. Boyd and G. B. REED. Gas-metal electrode potentials in sterile culture media - for bacteria. Canadian J. Res. 4, i, 54-68, January 1931.

The potentials obtained with gold, platinum and mercury electrodes in sterile buffered beef broth saturated with air, nitrogen, carbon dioxide and hydrogen are given. It was found that standing the broth anaerobically for a week and then holding the cell at $0^{\circ} \mathrm{C}$. increased the constancy of the potential obtained in any one experiment. (Standard deviation, 7 millivolts with platinum, and 22 millivolts with gold electrodes.)

Air caused a slow positive drift at all three electrodes. Hydrogen was without specific effect on gold and mercury, but caused a sharp drop with platinum electrodes. Cessation of the gas current caused a further fall before the return to the initial value. Stirring appeared to cause a negative drift irrespective of the nature of the gas. 
Carbon dioxide and nitrogen were found to be inert. Anaerobically aged broths were used in all these experiments and had attained a potential of the order of $-0.1 \mathrm{v}$. This treatment is therefore equivalent to the de-aeration of broth by nitrogen. In every case the gas metal potentials were found to be in agreement with those reported by French and Kahlenberg for potassium chloride solutions.

Mercury was found to be unreliable and apparently reacted with the medium. The authors suggest that culture potentials may be interpreted by the pressure of gas films on the electrodes.

J. G. Davis

H. J. Fuchs. Eine neue Schnellzentrifuge. (A new rapid centrifuge.) Z. Immun. Forsch. 69, i-ii, 180-6, 1930.

A type of centrifuge capable of reaching 14,000 revolutions per minute is described. This speed is made possible by reducing the air resistance to the revolving parts; in addition the usual heat production is largely avoided.

J. G. Davis

C. D. Commings. The use of acid fuchsin in Russell's triple sugar medium. J. Inf. Diseases, 47, iv, 359-66, October 1930.

Undecolorised acid fuchsin is recommended for the preparation of Andrade's indicator for use in differentiating the coli-typhosus group. The faint pink of the finished medium permits the detection of alkalinity. (The disodium salt (red) is converted by the alkali to the trisodium salt (colourless).)

The Russell medium (J. Med. Research, 25, 217) was found to give correct reactions for $E$. typhosus, Sal. paratyphosus A and B, E.dysenteriae and Esch. coli when undecolorised acid fuchsin was used as the indicator.

J. G. Davis

C. S. Mudge. A life cycle of a thermophilic organism. Proc. Soc. Exp. Biol. Med. 28, ii, 202-3, November 1930.

One characteristic apparent in the study of thermophilic organisms in pasteurised milk is the sharp rather than gradual increase in bacterial count, a generation time of from 5 to 8 minutes being shown. The conclusion is arrived at that in milk showing thermophilic growth, spores are abundantly present. The life cycle of the organism studied consisted of (1) an invisible spore, abundantly present, heat resistant, incapable of growth on laboratory media at $37^{\circ}$ and $60^{\circ} \mathrm{C} . ;(2)$ a vegetative cell (rod) resulting from the germination of (1), destroyed by heat, growing on laboratory media; (3) a spore forming in the rod (2), heat resistant; (4) a spore, heat resistant, non-stainable, incapable of growth on ordinary media; (5) a dormant spore, the dormancy being broken by heat, cold, acids and alkalis. Change from stage (5) to (1) starts the cycle over again. Modifications of the cycles are possible. W. L. Davres

E. W. ToDD. Virulence of haemolytic streptococci. II. The influence of oxygen on the maintenance of virulence in broth cultures. III. The influence of oxygen on the restoration of virulence to matt attenuated cultures. Brit. J. Exp. Path. 11, vi, 469-79, 480-8, December 1930.

II. This paper describes the investigations of matt virulent and the attenuated (avirulent) variants. The latter may be obtained by anaerobic subcultivation or by the action of small quantities of peroxide over short periods. They cannot be reverted to the virulent form by cultivation in aerated catalose broth. They retain their typespecific substance however, and regain virulence by cultivation in normal serum.

Virulence is maintained by cultivation at high oxygen tension, especially if peroxide accumulation is prevented by catalase.

III. It has been shown that virulence is lost anaerobically but maintained aerobically if peroxide formation is prevented. These findings are discussed in relation to the oxidation-reduction potentials attained by cultures of streptococci. 
It is suggested that the ability of serum to restore virulence is due to its oxygencarrying effect. The increase in virulence is dependent on the oxygen tension of the serum, the optimum being just below that point at which peroxide is formed.

J. G. Davis

G. Gorbach. Zur Kenntnis der Bakterienproteasen. (Bacterial proteases.) Archiv f. Mikrobiol. 1, iv, 537-76, November 1930.

$A$ useful summary of previous work on proteases is followed by an account of a detailed investigation of the proteolytic phenomena of six strains of $B$. pyocyaneus.

The enzymes are most readily formed in weakly acid, or neutral solution, and are produced on synthetic media. The optimal concentration of peptone is $0.2-0.4$ per cent. and of gelatine $0.5-0.8$ per cent. Maximum growth is reached before maximum enzyme activity. The pigment formation goes parallel with that of the enzyme. Optimum conditions for enzyme production are also those for pigmentation.

Gelatine, Witte peptone, leucyl-glycyl-glycine and leucyl-glycine are easily hydrolysed, the optimum $p \mathrm{H}$ varying with the substrate from 6.5 to 8.4 . The optimum temperature is $40^{\circ} \mathrm{C}$, and the rate of proteolysis is proportional to the amount of enzyme for low concentrations. Addition of cyanide appears to increase the scission of the gelatine. Heating to $100^{\circ} \mathrm{C}$. for 5 seconds is without effect, and for 20 seconds halves the activity of the enzyme. Dialysis does not decrease the enzymic activity. The thus purified enzyme contains no coagulable albumen and gives a negative Millon and tryptophane reaction.

It is absorbed by kaolin and is readily purified in this way, being removed in acid solution.

J. G. Davis

\section{B. C. J. G. KnIGHT and P. Frrdes. Oxidation-reduction studies in relation to bacterial growth. III. The positive limit of oxidation-reduction potential required for the germination of B. tetani spores in vitro. Biochem. J. 24, v, 1497-1502, 1930.}

The spores of $B$. tetani were subjected to different oxidation-reduction potentials which were maintained constant by the poising method previously described (Biochem. J. 2A, 1075).

Germination was completely inhibited at an $\mathrm{E}_{h}$ greater than $+0 \cdot 11$ v. at $p H 7$. J. G. DAvis

\section{F. HewrTr. Oxidation-reduction potentials of Pneumococcus cultures. I. Biochem.} J. 24, v, 1551-6, 1930.

Pneumococcus cultures resemble those of haemolytic streptococci in the potentials induced in media in which they are cultured. Thus both aerobically attain the high potential $\left(\mathrm{E}_{h}+0.4\right.$ to $0.5 \mathrm{v}$.) corresponding to peroxide formation, and are unable to maintain intensely reducing conditions with an abundant supply of oxygen. The difference between the high levels of these two organisms and those of staphylococci and $C$. diphtheriae is attributed to the effect of catalase on peroxide formation in the latter case. The effect of different media is recorded.

J. G. Davis

L. F. Hewitr. Oxidation-reduction potentials of Pneumococcus cultures. II. Effect of catalase. Biochem. J. 25, i, 169-76, 1931.

Catalase, if added to pneumococcus cultures, prevents the rise in potential subsequent to the logarithmic phase of growth which is apparently due to peroxide formation. Growth is also increased by the addition of catalase. The system removed by catalase does not account for the differences between aerobes and anaerobes. No differences could be detected between bacterial peroxide and hydrogen peroxide. Killed aerobes appeared to possess a reducing system other than catalase; erythrocytes were found to possess a slight poising action at $E_{h}+0.3 \mathrm{v} . \quad J . G$. Davis 
A. van RaAlte. New coli test. Chem. Weekblad, 27, 663, 1930. (Analyst, 56, 660, 199, March 1931.)

In examining milk, 1 c.c. is added to 9 c.c. of medium containing $10 \mathrm{~g}$. each of peptone and sodium chloride and $250 \mathrm{~g}$. of sodium carbonate per litre. Successive dilutions are then made from 1 c.c. of mixture and 9 c.c. of medium so as to give a range containing one part milk in 10,100, etc., to 100,000. These are tested for indole after 24 hours at $37^{\circ} \mathrm{C}$. No reaction should be obtained for a dilution of 1 in 10,000 of ordinary trade milk, or 1 in 100 of "model" or pasteurised milk. Carelessly prepared milk may give a positive reaction in dilutions of 1 in 100,000 . The 1 in 10 dilution usually gives negative results owing to coagulation.

\section{G. S. WiLsoN. The effect of the virulence of Bact. aertrycke of cultivation in atmo- spheres containing varying proportions of oxygen. J. Hyg. 30, iv, 433-67, November 1930.}

The virulence of $B$. aertrycke as affected by oxygen tension has been studied by growing a strain under known oxygen tensions. Sub-cultures were made daily and continued until about 90 had been made. Anaerobic cultures maintained a virulence similar to that of the control strain, oxygen tensions from 1 to 21 per cent. caused an increasing decrease and tensions above 40 per cent. produced a culture of increased virulence.

The author reviews the results of other workers and suggests that incubation under anaerobic conditions and in 80 to 100 per cent. oxygen has a stabilising effect on micro-organisms, whereas normal aerobic pressures have the reverse effect.

It is concluded that aerobic cultivation favours microbic dissociation and leads to the replacement of the initial virulent organisms by avirulent variants, and that the agent responsible is present after the stage of active growth has ceased. The addition of serum or blood sometimes favours the reversion of rough avirulent to smooth virulent organisms. Two of the hypotheses are put forward to explain the stabilising effect of anaerobic and hyperaerobic conditions: (1) the agents responsible for dissociation are not formed anaerobically and are oxidised by the high alkalinity and oxygen tension hyperaerobically, (2) virulence is determined by the intracellular $p H$ which tends to become alkaline under ordinary aerobic conditions.

J. G. Davis

$\mathrm{N}$. UYEr. The nature of the growth-promoting active principle in the potato in the cultivation of bacteria and especially of the tubercle bacillus. Amer. Rev. Tuber. 22, ii, 203-17, August 1930.

Potato exerts a marked stimulating effect on the growth of the tubercle bacillus. The effect is not due to the proteins or the salts of the potato.

Glycogen and tyrosine were quite inactive, but maltose, dextrose and inositol stimulated growth if a large inoculum were added, while starch and dextrin exerted a marked stimulation with small inocula. The latter, however, were not so potent as the potato itself.

(The author's distinction between metabolic stimulants (dextrose) and reproductive stimulants (starch) does not appear to be justified in the evidence presented in this paper. The results could be explained equally well by considering the sugars to be specific carbohydrate foodstuffs, and the effect of starch and dextrin due to the presence of traces of bacterial stimulants from which colloids are separated only with difficulty (cf. Biochem. J.23,61). Thus although potato starch was active the starchy fraction prepared from autoclaved potato by extraction with hot trichloracetic acid and precipitation with acetone was inactive. The "fractionative properties" of the factor are similar to those of other bacterial factors.)

$J, G$, Davis

Jour. of Dairy Research III 
R. Stenhouse Williams and W. A. Hoy. The viability of B. tuberculosis (bovinus) on pasture land, in stored faeces and in liquid manure. J. Hyg. 30, iv, 413-19, November 1930.

The viability of $B$. tuberculosis (bovinus) in exposed foess is governed mainly by the faeces causing disintegration of the faecal patches. Thus the periods over which survival was proved in faecal patches on pasture land were 5,2,2 and 4 months in winter, spring, summer and autumn respectively. In faeces stored in jars in a cool dark cellar virulent organisms were found after 12 months in those naturally infected and after 24 months (probably more) in artificially infected faeces.

In liquid manure stored underground, a gradual decrease in virulence was observed after 6 weeks although virulent bacteria were found after 4 months.

Six pigs were usually used for each test (twelve injections). Comparative tests with antiformin and Petroff's method showed that the former sometimes gave negative results from material shown to contain virulent bacteria by the latter method, a modification of which was therefore used.

J. G. Davis

E. Löwenstern. Technique of pure culture of tubercle bacilli from blood. Deuts. med. Wschr. No. 24, 1930.

By replacing peptone with asparagin in an egg medium and using the sulphuric acid method for the isolation of the tubercle bacilli from the blood of tubercular patients a much greater percentage of successes occurred.

E. C. G. MaDDOCK

R. Stodtmeister. Die Brauchbarkeit des Harnstoffverfahrens nach Dold zur Anreicherung von Tuberkelbazillen für den mikroskopischen und kulturellen Nachweis. (Use of Dold's urea enrichment method for microscopic and cultural detection of tubercle bacilli.) Zbl.f. Bakt. I, Orig. 118, iii-iv, 218-29; September 1930.

The author found that the development of tubercle bacilli was less affected by urea than sulphuric acid especially if washed before culture. Washing was not necessary, but better results were obtained with washing. If not washed, cultures grew best on glycerine potato. Tubercle bacilli are not sensitive to high osmotic pressure if not prolonged, but are so if the pressure is suddenly decreased.

E. C. G. MADDOCK

G. S. WILson. The gaseous requirements of Br. abortus (bovine type). Brit. J. Exp. Path. 12, ii, 88-92, April 1931.

$B r$. abortus (bovine) does not grow anaerobically. Contrary to the opinion of Bang a reduced oxygen tension does not enhance growth, and increased oxygen tensions do not permit growth in the absence of $\mathrm{CO}_{2}$. Both oxygen and $\mathrm{CO}_{2}$ are necessary, the optimal concentrations being 20 and 5-10 per cent. respectively.

It is suggested that $\mathrm{CO}_{2}$ acts as a specific cell-wall penetrant which raises the intracellular acidity. Other acids cannot replace it.

J. G. Davis

A. Harden and M. G. Macfarlane. Note on the reactivation of reductase in washed yeast preparations. Biochem. J. 25, iii, 818-21, 1931.

The removal of co-enzyme by washing may best be tested by the failure of the preparation to ferment hexosediphosphate. Addition of lactate, succinate or methylglyoxal to such a preparation restores the ability to reduce methylene blue. Hence it is concluded that a co-enzyme is not required for the action of the reductase.

\section{Dairy Bacteriology.}

J. G. Davis

D. R. WooD. A simple calculation of the limit of value of the microscopical examination of milk for tubercle bacilli. Analyst, 56, 660, 179-80, March 1931.

By deduction from mathematical consideration of the conditions of examining deposits for tubercle bacilli microscopically it is claimed that the value of this method 
is limited to the detection of from 10 to 500 bacilli per c.c. or, excluding cases of bulky deposits which are generally characteristic of tubercular mastitis (i.e. deposits of 2.5 c.c. or less from 100 c.c. milk), from 10 to 50 bacilli per c.c. This is 500 times less sensitive than the biological method.

W. L. DaviES

A. Lumière and A. DUBoIs. The distribution of Koch's bacilli, contained in milk, after separating the butter and casein. Paper at Acad. Sci. (Paris), January 5, 1931. (Nature, p. 389, March 7, 1931.)

Known amounts of tubercle bacillus were added to milk, the cream separated, and the casein separated from the butter milk in the usual way. The resulting whey and cream were free from bacilli, which appear to be concentrated in the casein. It is concluded that starting with tuberculous milk the maximum danger is in the cheese.

D. R. Wood and E. T. Illing. Investigation of the occurrence of B. abortus (Bang) in the milk of English herds (county of Somerset). Analyst, 56, 659, 105, February 1931.

Milk (100 c.c.) from each of 379 Somerset herds was centrifuged and the deposit injected subcutaneously into a guinea pig, which was killed after 4 weeks and culture from the interior of the spleen made on glucose, neutral red vitamin agar in 10 per cent. carbon dioxide at $37^{\circ} \mathrm{C}$. B. coli was usually not found. $B r$. abortus was found in the milk of four herds and identified by agglutination with standard anti-serum.

J. G. Davis

\section{J. H. Brown. Experiments on the shipment of milk samples for bacteriological} examination. Certified Milk, pp. 220-1, 1929.

Samples of milk when dried in small vacuum tubes and stored for some days yield approximately the same number and kinds of bacteria that were contained in the original milk.

Attempts to absorb milk in silica gel for delayed bacteriological analysis failed, as although the same types could be recovered the numbers were much diminished.

J. G. Davis

H. N. Heffernan. The most probable numbers of B. coli per 100 c.c. of milk. Certified Milk, pp. 73-5, 1929.

This paper is a report on the results obtained from examining 451 samples of certified milk for the most probable number of coli. This figure fell from 125-240 in 1928 to $2-4$ per 100 c.c. (1929). High coli was associated with high counts in all but two cases.

A modified McCrady table was used for the calculation of the results. ( $J$. Infect. Dis, 21, 287, 1917.)

J. G. Davis

J. H. Brown. The detection of Bacillus coli and related organisms in certified milk. Certified Milk, pp. 220-38, 1929.

This paper describes the attempts to detect $B$. coli (added artificially) in certified milk by plating and by fermentation tube methods. It was found that when few coliform organisms were present ( 1 to 10 per 0.1 c.c. as shown by Chalmers' taurocholate agar), gas sometimes failed to appear in the fermentation tubes. The Chalmers' medium is recommended for low count milk and it is suggested that plating in this medium followed by the fishing of suspected colonies on to Simmon's citrate agar would be a simple and reliable method for the determination of $B$. coli and $B$. lactis aerogenes in certified milk.

J. G. Davis 
R. J. Ramsay and P. H. TraCy. Food poisoning probably caused by orange-coloured staphylococcus from udders of apparently healthy cows. Proc. Soc. Exp. Biol. Med. 28, iv, 390-1, January 1931.

While studying the cause of malt flavour in raw milk one of the authors became ill with severe gastro-enteritis, showing symptoms of food poisoning. The suspected food was raw milk inoculated with a pure culture of an orange-coloured staphylococcus. Four kittens fed with the inoculated milk also contracted severe symptoms of food poisoning. Other cases of food poisoning have been traced to a similar type of toxin-producing staphylococcus. Staph. aureus produces a malt-like flavour in milk and the authors believe that the incriminated organism is identical with it.

W. L. Davies

H. Alfonsus and O. CoRrell. Nachweis von thermophilen Bakterien mittels der Reduktaseprobe bei $63 \mathrm{Gr}$. Cels. und ihre praktische Anwendung im Molkereibetrieb. (Detection of thermophilic bacteria by the reductase test at $63^{\circ} \mathrm{C}$. and its practical use in the dairy industry.) Molkereiztg. 1, 1237-9, 1930. (Zbl.f.d. ges. Hyg. 23, iii, 146, October 10, 1930.)

The methylene-blue reductase test at $63^{\circ} \mathrm{C}$. is recommended as a simple method for detecting the presence of thermophilic organisms in milk. (This has also been found by Meanwell who followed the growth of thermophilic organisms in a pasteurising plant by this method, the standard plate count being useless for the purpose.)

Milk produced and handled under clean conditions does not contain large numbers of thermophilic bacteria.

J. G. Davis

C. GoRINI. Acid proteolytic bacteria in pasteurised milk. Compt. rend. 191, 885-6, 1930. (Chem. Abst. 25, vi, 1291, March 20, 1931.)

The thermophilic, acid-proteolytic bacilli of the subtilus group are among the most harmful to the preservation of pasteurised milk. The preservation of milk after pasteurisation depends more upon the number of bacteria which have resisted the heat treatment than upon the types present.

M. Grimes, V. C. E. Kennelly and H. A. Cummins. A study of fungi found in butter. Sci. Proc. Roy. Dublin Soc. 19 (N.S.), xlvii, 549-69, October 1930.

A brief description is given of various fungi isolated from sweet cream butter during an investigation of the causes of deterioration of such butter. The resistance of these fungi, to high temperatures, their salt tolerance and their growth at low temperatures are recorded.

E. R. Hiscox

G. F. V. Morgan. Some colour-producing organisms in butter-washing water. New

Zealand J. Agric. 41, v, 315-8, November 1930.

An account of certain cultural characteristics and the influence on butter of four pigment-producing organisms isolated from the water supplies of dairy factories.

E. R. Hiscox

Boisseau and Mesnit. Rôle de la Monilia dans la fermentation du Pont-1'Évêque. (Rôle of Monilia in the fermentation of Pont-l'Évêque cheese.) C.R. Acad. Agric. France, 15, 580-3, 1929. (Biol. Abst. 4, xi, 2746, November 1930.)

The active agent in ripening is a Monilia. Growth of the mycelium throughout the cheese slowly breaks down the casein to $\mathrm{NH}_{3}$ and prevents growth of Oidium lactis and other moulds which would ripen the cheese too rapidly and would result in off flavours. Adequate growth of Monilı is assured by using milk 22-3 ${ }^{\circ}$ acidity (Dornic) or of $0.22-0.23$ per cent. lactic acid and by making the cheese in a warm room to aid acid production and draining off the cheese. Active growth of monilia, effective salting, acid curd, and proper temperature conditions are indispensable. 
W. STOcker. Ueber bakterielle Schwarzfärbungen des Käserinde. (Bacterial black discoloration in cheese rind.) Zbl.f. Bakt. II, 82, xv-xxii, 405-6, December 1930.

The occurrence of black spots on the rind of soft cheese usually accompanied by a darkening of the whole surface and extending to a few $\mathrm{mm}$. below the surface, was usually traced to the presence of Monilia nigra. In some cases, however, the mould was absent and the discoloration appeared to be due to bacteria which were capable of inducing a characteristic blackening in milk. There was no coagulation of the milk but complete digestion took place. The optimum temperature for the formation of the pigment was $12^{\circ} \mathrm{C}$. and the colour was intensified by an alkaline reaction.

E. R. Hiscox

G. Koestler. Ueber die von der Rinde her sich vollziehende Entsäuerung des Hartkäseteiges. (Complete deacidification of the curd of hard cheese from the rind inwards.) Land. Jahrb. d. Schweiz, pp. 1065-76, 1929.

By measurements of the hydrogen-ion concentration at different depths throughout the ripening, the author procures evidence to support Freudenreich's theory that hard cheese ripen uniformly throughout the mass. In addition, however, the experiments show that in cheese such as Emmental and Greuerz there is, side by side with the principal ripening processes, a gradual deacidification of the curd from the rind inwards due to the action of micro-organisms.

L. A. Allew

\section{CHEMISTRY (ORGANIC, INORGANIC AND PHYSICAL).}

\section{GeneraL.}

T. B. Brighton and C. M. Dice. Increasing the purity of common salt. Ind. Eng. Chem. 23, ni, 336-9, March 1931.

Substances causing an odour when refined common salt is dissolved in hot water are present in such minute amounts that their identification is not possible. Heating fine salt in an oxidising atmosphere above $210^{\circ} \mathrm{C}$. eradicates the odour. Since such heating causes discoloration of salt it is advisable to wash with brine before roasting. This treatment is possible on a commercial scale resulting in a whiter and purer dairy and table salt.

W. L. Davies

R. Cohen. Permeability of packing materials (cellophane, etc.) to water and water vapour. Chem. Weekblad. 28, 159-62, 1931.

On comparing the permeabilities of cellophane, duratex with that of parchment, the data obtained was so irregular that general conclusions only could be drawn. Permeability to moisture is inversely related to electrical insulating power both being connected with the presence or absence of free hydroxyl groups. W. L. Davies

R. J. BEST. The application of the quinhydrone electrode to the measurement of the acid reaction of unbuffered solutions. J. Phys. Chem. 34, viii, 1815-17, August 1930.

Values given by the quinhydrone electrode in unbuffered solutions (standard $\mathrm{HCl}$ of varying strengths) gave good agreement with theoretical values for $p \mathrm{H} 1$ to $p \mathrm{H} \mathrm{5.} \mathrm{At} \mathrm{values} \mathrm{above} \mathrm{this} \mathrm{unreliable} \mathrm{results} \mathrm{were} \mathrm{obtained.} \mathrm{(The} p \mathrm{H}$ of saturated aqueous quinhydrone is about 5.85.) Equilibrium was established in $\frac{1}{2}-1 \frac{1}{2}$ minutes. Electrodes only washed and then immersed in another solution drifted to an equilibrium value.

J. G. Davis 
J. L. R. Morgan, O. M. Lammert and M. A. Campbeli. The quinhydrone electrode. I. J. Amer. Chem. Soc. 53, ii, 454-69, February 1931.

The reproducibility of the quinhydrone electrode under different conditions of electrode size, age and composition has been studied. Generally, reproducibility with ease and precision is attainable but the greatest source of error lies in the preparation of the metal electrode. A method for the preparation of a robust, serviceable electrode is given. Cracks in the glass cause relatively large errors and results obtained from alcohol flaming of the electrode do not justify risks following on the formation of minute cracks. Electrodes of long wire or of foil, which need not be of a greater dimension than $1 \mathrm{~cm} .^{2}$, give greater precision than short wires, which generally give erratic results. The composition and age of the metal is of little importance although old roughened platinum foil (less than $1 \mathrm{~cm} .^{2}$ ) gave the best results in $0.1 \mathrm{~N}$ hydrochloric acid.

W. L. DAvies

\section{O. M. Lammert, J. L. R. Morgan and M. A. CampbelL. The quinhydrone electrode. II.} J. Amer. Chem. Soc. 53, ii, 597-604, February 1931.

In investigations of the effect of nitrogen on the reproducibility of the quinhydrone electrode (in $0 \cdot 1 \mathrm{~N} \mathrm{HCl}$ ) it was found that more reproducible results were given by either drying the electrodes in nitrogen or preparing with solutions stirred with nitrogen than by electrodes prepared in air or oxygen. Saturating the liquid of the half-cell with nitrogen also gave more consistent results. In the presence of nitrogen, equilibrium potential was reached more quickly and short circuiting pairs of electrodes had no effect on the P.D. obtained in nitrogen. The authors claim that the $0.1 \mathrm{~N} \mathrm{HCl}$ quinhydrone half-cell prepared in this way is the most easily and quickly reproducible electrode which they have used.

W. L. Davies

E. H. LEPPER and C. J. MARTIN. On the behaviour of "indifferent" electrodes when used for the determination of oxidation-reduction potentials in the presence of hydrogen. Biochem. J. 25, i, 45-8, 1931.

The behaviour of gold and iridium electrodes in poised and unpoised buffer solutions and in the presence of nitrogen, oxygen and hydrogen has been examined.

Hydrogen is much more readily adsorbed by the iridium electrode which in the presence of this element tends to function as a hydrogen electrode. $0.002 M$ indigo carmine "poised" the iridium electrode, but when the concentration was reduced to $0.0001 M$ the electrode attained the potential of the hydrogen electrode in half an hour.

J. G. Davis

A. TAFFel and C. Revis. The determination of the rancidity in oils and fats. J. Soc. Chem. Ind. 50, xi, 87-91 T, March 13, 1931.

Oils, air-blown or allowed to become rancid at various temperatures, contain a proportion of easily reducible peroxides (by hydriodic acid) and some other form of oxygen less easily reducible. This latter form of oxygen increases in proportion with the temperature of blowing. Oils blown at $170^{\circ} \mathrm{C}$. contain mostly the less easily reducible oxides. Methods are described to evaluate the amount of each type of oxide present in an oil.

A modified Kreis test is described which is claimed to give more accurate comparative results. Intensity of colour with the Kreis reaction followed closely the peroxide content of oils.

The two modified tests are advantageous in that they can be universally applied to any type of rancid oil with definite and reproducible results and in being able to distinguish oils which have been blown at high temperatures from those which have grown rancid normally.

W. L. Davies 
A. F. MoCARLEY, Some new colour reactions with certain oils and fats. Analyst, 56, 659, 104-5, February 1931.

Certain phenols give well-marked colour reactions in chloroform solution with certain oils and fats in the presence of bromine in excess. Three drops of oil are added to a saturated solution of resorcinol in chloroform and five drops of strongly brominated hydrochloric acid added. A colour gradually forms on shaking. Various oils including cod-liver oil and butterfat give varying shades of pink. Probably colour development is associated with Vitamin A content since the unsaponifiable matter gives the colour reactions and the separated fatty acids do not. Cod-liver oil gives the most pronounced coloration, followed by butterfat, which is much less reactive.

W. L. Davies

D. P. Grettete and R. C. Newton. Measurement of rate of formation of oxidative decomposition products in fats and oils. Ind. and Eng. Chem. (anal. ed.), 3, ii, 171-3, April 1931.

$2 \mathrm{~g}$. of fat are soaked into a pleated filter paper sheet which is inserted into a tube passing through an air oven maintained at $100^{\circ} \mathrm{C}$. A slow stream of air (1 c.c. per second) is drawn through the tube and bubbled through a solution of $0.01 \mathrm{~N}$ permanganate acidified with sulphuric acid kept at $25^{\circ} \mathrm{C}$. in a water bath. The volatile products of fat oxidation reduce the permanganate, the amount of reduction being determined during suitable periods of time (20 minutes). It is found that the odour of rancidity developed when the volatile products are sufficient to reduce 1 c.c. of $0.01 \mathrm{~N}$ permanganate in 20 minutes.

W. L. Davies

\section{J. Grossfeld and F. Battay. Versuche über Nachweis, Bestimmung und Vorkom-} men der Buttersäure in Lebensmitteln. (Detection, determination and occurrence of butyric acid in foodstuffs.) Z.f. Unters. Lebensm. 61, ii, 129-61, February 1931.

One part of butyric acid in 12,500 is detectable from its odour by distilling the aqueous solution after removal of other substances by oxidation with permanganate. Details are given for the method of distillation (phosphoric acid), oxidation of other volatile substances and extraction of higher fatty acids. A method for the analysis of the resulting liquid for acetic and butyric acids is given. Milk was found to contain 0.004 per cent. (sweet) and 0.008 per cent. (sour), while cheese varied in content of free butyric acid from 0.066 to 1.340 per cent. according to the type of cheese.

W. L. Davies

E. O. Whittuen and S. P. GouLd. Speed of crystallisation of lactose, galactose, glucose and sucrose from pure solution. Ind. and Eng. Chem. 23, vi, 670-2, June 1931.

In the earlier stages of crystallisation of lactose, the rate of crystallisation of the isomeric form separating is the principal factor. Later, the rate is decreased, and the rate of attainment of equilibrium between isomeric forms becomes the controlling factor. The most rapid crystallisation of lactose occurs from a solution maintained at $30^{\circ} \mathrm{C}$. for 3 hours which is then allowed to cool to $20^{\circ} \mathrm{C}$ W. L. Davies

H. P. Morris, J. W. NELSON and L. S. PALMer. Quantitative determination of calcium, magnesium and phosphorus in feedstuffs and cattle excreta. Ind. and Eng. Chem. (anal. ed.), 3, ii, 164-7, April 1931.

With materials containing large quantities of substances insoluble in hydrochloric acid, such as hay and faeces, the determinations of calcium and magnesium tend to give low results owing to the occurrence of these metals as complex silicates. These silicates are broken down by fusion with sodium carbonate in platinum vessels. 
Silicic acid does not interfere with the volumetric estimation of calcium, but the dehydration method of removing silicic acid must be resorted to in the gravimetric estimation.

W. L. Davies

\section{W. J. WILEy. The dissociation of calcium citrate. Biochem. J. 24, iv, 856-9, 1930.}

Measurements were made of the conductivity of calcium citrate solutions of different dilutions, and confirmation obtained by conductivity titrations of citric acid solutions with calcium hydroxide solutions. The small values obtained for the degree of dissociation of tricalcium citrate in dilute aqueous solutions are recorded.

S. J. RowLAND

\section{DAIRy Chemistry.}

G. D. Elsdon and J. R. StubBs. The freezing-point of milk and its applications. J. Soc. Chem. Ind. 50, xvi, 135-41 T, April 17, 1931.

A review is given of the apparatus used for the determination of the freezing-point of milk, with a detailed description of the Hortvet apparatus and method, together with the results obtained by various workers. The depression of freezing-point obtained by the authors for a large number of genuine milk samples ranged from $0.533^{\circ}$ to $0.559^{\circ}$, with an average of $0.543^{\circ}$. The various corrections for acidity applied by different workers are discussed and it is suggested that, owing to ignorance of the acidity of the fresh sample of an unknown milk examined after further acidity has developed, only fresh samples of milk should be worked on. When acidity is reckoned as $\mathrm{ml} .0 \cdot 1 \mathrm{~N}$ soda per $10 \mathrm{ml}$. of milk, and when the acidity of a milk sample exceeds $2 \cdot 5$, a rough value of the freezing-point of the original milk can be obtained by subtracting 0.003 from the observed depression for every $0.1 \mathrm{ml}$. over $2.0 \mathrm{ml}$. of $0.1 \mathrm{~N}$ soda.

The value of the test is discussed and examples are given of the detection of added water by this method. The average depression for genuine milk may be taken as $0.54^{\circ}$, but no sample should be considered as watered on the evidence of a single sample unless this falls below $0.53^{\circ}$.

W. L. Davies

G. W. Monier-Williams. The nitrate test for the detection of added water in milk. Analyst, 56, 663, 397-8, June 1931.

The blue colour formed in this test is due to the quinone-imonium salt of diphenylbenzidine. Some of the nitrate is used for the oxidation of some diphenylamine to diphenylbenzidine and the second oxidation forms the blue colour. If only a trace of nitrate is present in the milk, it may happen that no nitrate is left to carry out the second oxidation. Hence, it is suggested that diphenylbenzidine should be used to give a more sensitive reaction. Details of the method of preparation of diphenylbenzidine from diphenylamine are given.

W. L. Davies

\section{G. Jørgensen. The rising of fat in milk. Analyst, 56, 663, 380-2, June 1931.}

This is a criticism of Stock's findings (Analyst, 55, 535, 1930) on the same question. When milk is allowed to stand in a churn the percentage decrease in the fat content of the lower layer of milk is greatest in the first hour of standing, but the rate of decrease depends on the diameter of the container, the narrower the container the less the decrease of fat content. Samples of milk show considerable variation in velocity of fat rising. The possibility of an increase of the solids-not-fat content of the cream layer by adsorption, evaporation and oxidation is discussed.

W. I. Davies 
K. SARLo. Determination of the sodium bicarbonate added to milk. Chem. Ztg. 55, 374-5, 1931. (Brit. Chem. Abst. B, p. 651, July 10, 1931.)

The solid residue obtained by evaporating 10 c.c. of milk is carefully ashed, taken up with $\mathrm{H}_{2} \mathrm{O}$, and treated in the presence of a few grams of $\mathrm{Zn}$ with a few c.c. of 20 per cent. $\mathrm{HCl}$, in a special apparatus. The mixture of $\mathrm{CO}_{2}$ and $\mathrm{H}$ is bubbled slowly through 22 c.c. of saturated $\mathrm{CaO}$ water of known concentration for 30-35 minutes. The residual $\mathrm{Ca}(\mathrm{OH})_{2}$ is then titrated with $0.04 \mathrm{~N} \mathrm{H}_{2} \mathrm{SO}_{4}$ against methyl-orange. Normal milk ash contains $1.5-2 \cdot 0$ per cent. $\mathrm{CO}_{2}$ and a deduction of 1.8 c.c. from the titre is made in evaluating the amount of added bicarbonate, which is then given by the formula $\mathrm{NaHCO}_{3}$ (mg./l.) $=336 \times(22-1 \cdot 1 \mathrm{v} .-1.80)$, where $\mathrm{v}$. is the volume of $\mathrm{H}_{2} \mathrm{SO}_{4}$ required. If the factor 1.6 is used instead of 336 , the "neutralisation" of the mill in degrees acidity is given. The method is sensitive to within $1^{\circ}$ acidity and is suitable for routine testing.

W. Mohr and C. Brockman. Oberflächenspannungsmessungen an Milch. (Surface tension measurements of milk.) Milchw. Forsch. 10, i-ii, 72-95, May 1930.

The authors have measured the surface tension of milk both by a "torsion" and by a "drop" method. Although the results obtained by both methods usually run parallel, those of the "drop" method are consistently higher.

The authors suggest that membrane formation is the cause of anomalous results which are obtained when determining the surface tension of skim milk.

Different methods of treatment such as low temperature pasteurisation, high temperature pasteurisation, repeated boiling and sterilisation are entirely without influence on the surface tension of milk, as also are ageing, freezing and the addition of formalin.

An increased air content causes a rise in the surface tension. With increasing acidity the surface tension diminishes, as the calcium caseinate is split up.

E. C. V. MatTick

\section{G. KoestLeR. Weitere Untersuchungen ueber Ziegenmilch. (Recent research on} goat's milk.) 1930. Liebefeld, Bern.

This paper reports the studies of the composition of numerous samples of goat's milk (and comparison of it with cow's) which were carried out in the hope of elucidating the anaemia which occurs in animals fed on it. Goat's milk had been found to be adequate for growth of rats on a vitamin free ration and equivalent to cow's. It is constantly higher in chlorine content than cow's milk and the low bacterial counts of the milk show that such a difference as this is due to normal secretory activity of the gland and not to disease. Other differences noted in goat's milk were (1) lower lactose concentration, (2) lower in nitrogenous constituents, (3) lower in citric acid, (4) notably low cholesterol content, and (5) less tendency to lactic fermentation, with very delayed clotting. During the colostrol period goat's milk is closely analogous to cow's. The fat of goat's milk contains odoriferous matter, probably a mixture of volatile fatty acids (especially caprytic and caproic).

G. L. Peskett

\section{H. Whitnah. Indications of glucose in milk. J. Amer. Chem. Soc. 53, i, 300-4,} January 1931.

Fermentation of milk with washed bakers' yeast was found to remove added glucose completely without acting on lactose. Applying this method for the detection of glucose occurring naturally in milk, it was found that in 275 samples examined, a decrease in specific rotation after yeast treatment gave glucose contents varying from zero to 0.35 per cent. Eleven other samples showed slight increases in rotation after fermentation.

W. L. Davies 
H. T. Gebhardt and H. H. Sommer. Determination of copper in dairy products. Ind. Eng. Chem. (anal. ed.), 3, i, 24-6, January 1931.

A modified Biazzo method for the colorimetric determination of small traces of copper in dairy products is described. Ashing of milk at temperatures above $565^{\circ} \mathrm{C}$. was found to cause loss of copper, and it is recommended not to exceed that temperature in the ashing process. The precipitated copper sulphide is collected in a chloroform layer instead of by filtering, the chloroform being finally boiled off. The subsequent procedure follows that of the Elvehjem-Lindow method. Testing the method by adding known amounts of copper to milk and recovering gave satisfactory results.

W. L. Davies

L. H. LAMPITT and M. BogoD. The determination of lactic acid in milk and milk products. C.R. IX Cong. Chim. Indust., Chim. et Ind., Spec. No. 510-5, March 1930. (Chem. Abst. 24, xxi, 5386, November 10, 1930.)

The method depends on the oxidation of lactic acid to acetaldehyde by means of potassium permanganate. To $10 \mathrm{~g}$. of milk, $4 \mathrm{~g}$. of condensed milk, or $1 \mathrm{~g}$. dried milk, are added $10 \mathrm{ml}$. of $0.01 \mathrm{~N} \mathrm{NaOH}$ and $30 \mathrm{ml}$. of water. After boiling and cooling, the liquid is transferred into a $100 \mathrm{ml}$. flask $10 \mathrm{ml}$. of $0 \cdot 1 \mathrm{~N} \mathrm{H}_{2} \mathrm{SO}_{4}$ added and $5 \mathrm{ml}$. of phosphotungstic acid reagent (saturated solution in $N$ hydrochloric acid), cooled and made up to the mark. Twenty $\mathrm{ml}$. of a filtrate from this are transferred to a $50 \mathrm{ml}$. flask, $2 \mathrm{ml}$. of saturated copper sulphate solution and $3 \mathrm{~g}$. of $\mathrm{Ca}(\mathrm{OH})_{2}$ are added, and made up to the mark. After standing for 20 minutes the contents are centrifuged (20002500 r.p.m.) for 5 minutes, the clear liquid filtered. Of the filtrate $25 \mathrm{ml}$. are transferred to a $250 \mathrm{ml}$. distillation flask containing a little talc and $10 \mathrm{ml}$. water; $1 \mathrm{ml}$. of $5 \mathrm{~N} \mathrm{H}_{2} \mathrm{SO}_{4}$ are added and the flask attached to a condenser. A dropping funnel containing $100 \mathrm{ml}$. of $0.004 \mathrm{~N} \mathrm{KMnO}_{4}$ is fitted. An adapter at the end of the condenser fits into a flask (100-110 ml.) containing $10 \mathrm{ml}$. of $0.02 \mathrm{~N}$ (approx.) sodium bisulphite solution, the tip being below the level of the liquid. On heating the flask, as soon as boiling begins, the permanganate solution is allowed to drop on to the boiling liquid; boiling is carried on for 50-60 minutes, the dropping being so regulated as also to take this time (80-100 ml. distillate). The excess of bisulphite in the receiver is titrated with $0.01 \mathrm{~N}$ iodine and the bisulphite in $10 \mathrm{ml}$. of the original bisulphite solution also determined. The difference in the titrations multiplied by 0.45 gives the amount of lactic acid in $\mathrm{mg}$. Loss of lactic acid during the clarifying processes amounts to about 10 per cent., so that a truer value of the lactic acid is obtained by multiplying the found value by 10/9. Determinations carried out on milk show that the total lactic acid content of normal milk is less than the equivalent of the titratable acidity. This difference diminishes or changes its sign if added alkali is present. W. L. DAvIES

A. StafFe. Sur quelques composants et propriétés du lait des vaches castrées. (Some components and properties of the milk of castrated cows.) Le Lait, 10, c, 1087-96, December 1930.

W. H. E. REID. Effect of pasteurisation temperature on the physical properties of milk. Missouri Agric. Exp. Sta. Res. Bull. 126, 1929. (Brit. Chem. Abst. B, p. 1128, December 12, 1930.)

The viscosity, specific gravity and surface tension are not materially affected by the use of different pasteurisation temperatures; rise of the temperature retards the separation of fat. 
C. K. JoHns. Modification of the methylene-blue reductase test and its comparative value in determining the keeping quality of milk. Sci. Agric. 11, 171-90, 1930. (Brit. Chem. Abst. B, p. 271, March 20, 1931.)

The modifications ensure greater convenience and accuracy of working (especially with high-grade milks) and closer correlation with the keeping quality. A preliminary incubation at $12.8^{\circ}$ for 18 hours is adopted, and in the subsequent incubation at blood heat tubes not discoloured after 6 hours are shaken to redistribute bacteria carried to the surface with the rising butterfat.

K. YAMAMURA. Effect of the heating temperature of milk and estimation of the heating temperature of dairy products. J. Agric. Chem. Soc. Japan, 6, 462-73, 1930. (Chem. Abst. 24, xxi, 5387, November 10, 1930.)

A. E. Perkins. Relation between the quantities of fat and protein in normal milk. Ohio Agric. Exp. Sta. Bull. No. 446, 126-7, 1930. (Brit. Chem. Abst. B, p. 271, March 20, 1931.)

From analyses of grouped samples of milk the following formula is derived: protein (per cent.) $=2 \cdot 78+[0.42$ (fat per cent. $-2 \cdot 78)] \pm 0.25$. The probable error of single determinations from mixed milk is likely to be smaller than that shown above.

G. N. QUAM. The temperature effect on the solubilities of nickel, tin, copper, steel (chromium) and zinc in raw cow milk. Proc. Iowa Acad. Sci. 36, 261-2 (1929).

(Chem. Abst. 25, vi, 1291, March 20, 1931.)

The solubility curves for $\mathrm{Ni}, \mathrm{Cu}$ and $\mathrm{Zn}$ show a maximum within a range of $75^{\circ}$ to $85^{\circ}$. Sn shows an accumulation of sturdy corrosion product above $75^{\circ}$, while the Cr steel (super-ascoloy) shows no apparent change.

D. R. Wood, E. T. Illing and A. E. Fletcher. The diphenylamine test for nitrates in milk as a means of detecting added water and the effect of drenching cows with "nitre." Analyst, 56, 661, 248-9, April 1931.

Lerrigo's test (Analyst, 55, 433, 1930) was used for this investigation and found to be satisfactory. No samples of genuine milk gave tests for nitrates. Five per cent. added water could be detected if the water contained 0.5 parts per 100,000 of nitrate nitrogen. Cows drenched with $\frac{1}{3}$ oz. of "nitre" daily did not cause any nitrate to be secreted in milk. Attention is drawn to filter paper sometimes containing sufficient nitrate to cause fictitious results.

W. L. Davies

G. E. Horm and B. H. WeBB. Buffer capacities of various milks and proprietary infant foods. Amer. J. Dis. Child. 40, 260-8, 1930. (Physiol. Abst. 15, x, 587, January 1931.)

Any correlation observed between buffer capacities and types of curd formed is probably accidental, and in infant feeding the nature of the curds formed is of greater importance than is the buffer capacity.

A. Schneck and H. Mengebier. Ueber die Extinktion der Milch. (Opacity of milk as measured by the extinction coefficient.) Milchw. Forsch. 11, i-ii, 1-29, October 1930.

Under strictly controlled conditions light transmission in milk is proportional to the concentration of the constituents, the Lambert-Beerscke law for solutions applying. The fat phase has little effect. Dilutions of milk from 1 to 100 also obey the Lambert-Beerscke law. Skimming depressed the extinction by 4 per cent. in many of the samples tested. Milk samples from individual cows differ in extinction coefficients. The small effect due to fat varies with the average size of the fat globules. 
Ministry of Health. Sale of Food and Drugs Act. Extract from 1929-30 Annual Report and Reports of Public Analysts 1929. (Analyst, 56, 659, 110-11, February 1931.)

Milk. Of 68,115 samples examined, 5293 (7.8 per cent.) were reported against (previous year $8 \cdot 2$ per cent.). Outstanding cases were deficiencies in fat of 43.3 and 10.3 per cent. Dirt was present in 22 samples, annatto in 10 , and 5 samples contained preservatives. There were 13 cases of added water to separated or skimmed milk. Out of 226 samples of dried milk, 3 were reported against and out of 1294 samples of condensed milk 41 were deficient, mostly in fat.

Cream. Out of 51 adulterated creams (2368 samples) 37 contained boron preservative, 10 tinned creams were low in milk fat or solids. Two samples of "fresh" cream were reconstituted.

Butter. Out of 10,965 samples of butter, 149 were reported against, 81 containing excess water, 49 containing foreign fats and 19 with boron preservative.

Cheese. Of 1321 cheese samples, 27 were adulterated. Generally they did not attain the composition necessitated by their description. No tin-wrapped cheese examined was free from tin contamination.

W. L. Davies

\section{G. T. Pyne. The detection of viscogen in cream. Analyst, 55, 657, 747-9, December} 1930.

Viscogen (calcium saccharate) owes its thickening properties mainly to the interaction of its calcium with soluble phosphates in milk and cream whereby gelatinous tricalcic phosphate is formed. The addition of soluble oxalate leads to the formation of calcium oxalate which reverses the thickening effect of the saccharate. The test thus consists of comparing the viscosities of a cream before and after adding potassium oxalate solution. Cream containing viscogen shows a very large drop in viscosity on the addition of oxalate, but cream with no viscogen shows a slight rise in viscosity. Certain precautions as to mixing and adjustment of acidity of the cream after the addition of oxalate have to be observed.

W. L. Davies

\section{P. H. Tracy and H. A. Ruere. Factors affecting the heat coagulation of homo- genized coffee cream. Illinois Agr. Exp. Sta. Bull. 352, 1930.}

The following factors are contributory to the feathering of fresh cream in coffee: the presence of calcium salts in the water used for making coffee, and excess of soluble calcium salts in the cream, high fat content of the cream, increasing the viscosity of the cream by homogenisation at low temperature, increasing the fat-adsorbing area in the cream by increased homogenising pressures and using an improper combination of pressures when using the two-stage homogeniser. Feathering may be controlled by using water of low calcium content for coffee making, the addition of sodium bicarbonate, citrate or phosphate to the cream (if legally permissible), pasteurising the cream at $155^{\circ} \mathrm{F}$. for 30 minutes and homogenising at $500-1000 \mathrm{lb}$. pressure for the single-stage machine or, with the two-stage machine, at a total pressure of 1500-2500 with 500-1000 lb. pressure on the second valve. A daily laboratory test on each batch should be carried out.

W. L. Davies

E. ELSER. Semi-micro methods for the analysis of condensed milk. Mitt. Lebensm. Hyg. 21, 314-20 (1930). (Chem. Abst. 25, vi, 1291, March 20, 1931.)

About 8-9 g. of condensed milk is diluted to 200 c.c. with water. For total solids 20 c.c. is evaporated with pumice on the steam bath, then at $100^{\circ}$ in vacuo for 2 hours. For sugars the proteins in 50 c.c. are peptonised with $\mathrm{CuSO}_{4}$ solution and 20 c.c. of the filtrate is taken for lactose and similarly for sucrose. Total protein and albuminglobulin are determined by the micro-Kjeldahl method. Fat is estimated in 11 c.c. with the Gerber butyrometer. $\mathrm{Cl}$ is determined by treating 20 c.c. with concentrated 
$\mathrm{HNO}_{3}$ and $0.02 \mathrm{~N} \mathrm{AgNO}_{3}$, destroying proteins with perhydrol and titrating back with $0.02 N$ KCNS. Ash is determined on the undiluted product, which is dried first at $70^{\circ}$ and then at $120^{\circ}$ in vacuo before ashing. The ash is dissolved in $\mathrm{HNO}_{3}$ and used for determination of $\mathrm{Ca}, \mathrm{K}, \mathrm{Fe}$ and $\mathrm{P}_{2} \mathrm{O}_{5}$.

L. H. Lampitt and J. H. Bushill. Physico-chemical constitution of spray-dried millk powder. Fat in spray-dried milk powder. J. Soc. Chem. Ind. 50, vi, 45-54T, February 6, 1931.

The "free" fat of milk powder, or fat extractable by organic solvents varied from 3.3 to 14.2 in spray-process milk powder, and 91.6 to 95.8 for roller-process powder, the results being calculated on total fat. The extraction process consisted of allowing $2 \mathrm{~g}$. of powder to remain in contact with $100 \mathrm{ml}$. of a fat solvent (carbon bisulphide)

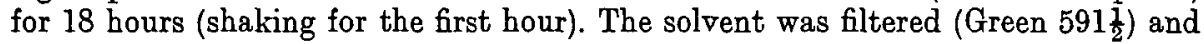
the dissolved fat determined by weighing after distilling off the solvent. For high "free" fat powders this value agreed well with that obtained by Soxhlet's method. Grinding the powder increased the amount of "free" fat to 83 per cent. of the total fat for the spray-process powder, and to practically all the fat of the roller-process powder. The reasons for these differences are dealt with. The behaviour of milk powder when absorbing moisture was remarkable, in that it first became clammy, then hard and powdery, this stage corresponding to the "freeing" of the fat, and was called the condition of "critical moisture" content (8.6-9.2 per cent. moisture). Amorphous lactose crystallised at this point. Drying out this absorbed moisture did not cause reversion to the original condition. The critical moisture range was found to be proportional to the solids-not-fat content of the powder. Lactose in its amorphous state thus had a marked effect on the availability of the fat to solvents and crystallisation of the lactose "frees" the fat.

W. L. Davies

\section{E. S. Guthrie. Air in butter. J. Dairy Sci. 13, vi, 461-70, November 1930.}

A method for determining air in butter depending on the fact that air would be the only constituent of butter capable of expanding in a vacuum, has been described. The air content of thoroughly worked butter was higher than that of well-worked butter, although a great variation was encountered between the values for identically treated samples. An average air content (by volume) of well-worked butter was 4.65 per cent. and that of thoroughly worked butter, $5 \cdot 37$ per cent. This variation in air content is of significance in the marketing of butter, where print butter is packed by volume and sold by weight.

W. L. DAviES

\section{R. Bhattacharya and T. P. Hilditch. The fatty acids and component glycerides of Indian ghee. Analyst, 56, 660, 161-70, March 1931.}

Two samples each of buffalo and cow ghee have been investigated. The samples of cow ghee, one from a stall-fed, the other from a pasture-fed animal gave figures which lie between the limits of eight English and New Zealand butters already examined. The R.M. values were low and the oleic acid contents were of average value. Stearic acid was higher in the fat of the stall-fed animal. The buffalo ghees were characterised by relatively lower contents of oleic and linoleic acids, but a higher content of butyric acid. Stearic acid was higher, and there were small but definite amounts of arachidic acid present. The g]yceride structure of these fats confirmed previous findings in that the esters are of the mixed "heterogeneous" type. The saturated fatty acids were found in each part of the fat-fully saturated and mixed saturated-unsaturated triglycerides. Tripalmitin, tristearin and triolein would be present only in small amounts.

W. L. Davies 


\section{BIOCHEMISTRY.}

T. P. Hifditch and J. J. Sleightholme. The glyceride structure of butterfats. Biochem. J. 25, ii, 507-22, 1931.

Analytical data are given for the fatty acids present in the fully saturated glycerides of four English butterfats and one New Zealand butterfat. The component fatty acids of the whole butterfats having been previously determined (Hilditch and Sleightholme, Biochem. J. 24, iv, 1098, 1930), the general features of the glyceride structure of butterfats are discussed, as revealed by these figures taken in conjunction with those formerly obtained for two New Zealand butterfats (Hilditch and Jones, Analyst, 54, 75, 1929). Consideration is given to the general distribution of unsaturated acids throughout the glycerides, and to certain regularities in the occurrence of the saturated acid components in all the fats except the two obtained from cows receiving specific oil-cakes in their diet.

S. J. RowlaND

I. PASzToR. Die Veränderung des Wassergehaltes beim Käseschmelzen. (The change in water content during the processing of cheese.) Kisérl. Közlemenyek, 32, 492, 1929. (Milchw. Forsch. 10, i-ii, Ref. 35, May 1930.)

The water content of Emmental increases during processing on an average by 8.8 per cent., that of Romadur by 5.3 per cent. from that of the original raw cheese.

The moisture content of processed Emmental cheese of good quality lies between 42 and 46 per cent., while that of Romadur lies between 50 and 55 per cent. It depends upon the water content of the raw cheese, the amount of citrate solution which is added, and the period of steam heating in the vacuum. E. C. V. MatTICK

G. Wode. Détermination du $p \mathrm{H}$ dans le jus de fromage. $(p \mathrm{H}$ determination of the press extract of cheese.) Le Lait, 10, c, 1083-7, December 1930.

Time-potential measurements obtained when measuring $p$ H values of cheese by the quinhydrone method are discussed. It is shown that the apparent rise in $p \mathrm{H}$ noticeable within 5 to 10 minutes after the electrode has been in the quinhydrone cheese pressed extract mixture increases with the age of the cheese and is correlated with the appearance of a red colour caused by reaction between the quinhydrone and the amino acids of the cheese. Addition of water to the cheese juice increases the period of stability of the potential and also inhibits the coloration, but slightly raises the $p \mathrm{H}$.

J. G. DAVIS

S. PASZTOR. Die Bestimmung der Wasserstoffionekonzentration im Schmelzkäse mit Hilfe der Chinhydronmethode. (Determination of hydrogen ion concentration in processed cheese by means of the quinhydrone electrode.) Molkereiztg. Hildesheim, No. 98, 1831, 1930. (Milchw. Forsch. 11, i-ii, Ref. p. 27, October 1930.)

Addition of water to cheese raised its $p \mathrm{H}$ by about 0.04 ( 1 vol.) up to about 0.60 (99 vols.).

The initial values were about $5 \cdot 5$.

J. G. DAVIS

B. Dyer and G. TAYLoR. County of Essex-Report of the County Analyst for the fourth quarter, 1930. Tin in cheese. Analyst, 56, 661, 251-3, April 1931.

Of 35 samples examined during the quarter none was entirely free from tin, the variation being 0.3 to 5.5 grains per pound ( 43 to 786 p.p.m.), the higher figure being an exceptional maximum.

Based on the investigations of the Ministry of Health in 1908 on the tin contamination of "canned" foods the authors suggest that contamination up to 2 grains per pound (286 p.p.m.) need not be taken too seriously, whereas anything above 


\section{Biochemistry}

this arbitrary figure should be regarded as excessive. Twenty-eight (or 80 per cent.) of the samples did not exceed this limit. These included prepared cheese from homemade and Dominion Cheddars and a large proportion of continental origin (Gruyère). The seven samples containing tin above the arbitrary limit were Swiss or French Gruyère. It is suggested that packers should pay more attention to quality of foil used and to the shortening of the interval between the packing and consumption.

W. L. Davies

\section{C. Carpenter. The molecular weight of casein. III. J. Amer. Chem. Soc. 53, v,} 1812-26, May 1931.

Previous work has shown the molecular weight of casein to lie between 75,000 and 100,000. Analyses of casein for various elements and groupings have given the following figures: sulphur, 0.785 per cent.; phosphorus, 0.856 per cent.; cystine, 0.488 per cent.; tryptophane, 1.237 per cent.; tyrosine, 5.55 per cent.; histidine, 1.776 per cent. Multiples of the lowest molecular weight needed to contain one atom or one molecular residue of the above list agree with extraordinary accuracy to give a molecular weight ranging from 97,796 to 98,988 , an average of 98,000 being taken as the probable value. A molecule of casein of this molecular weight contains 24 sulphur and 27 phosphorus atoms, 2 cystine, 6 tryptophane, 30 tyrosine, and 11 histidine molecules in its constitution.

W. L. Davies

G. M. MoIr, Determination of the mills proteins. I. The chemistry of the separation of casein. II. The identity of the casein precipitate. III. Proposed modified method for casein. IV. A. The combined determination of albumin and globulin. B. The separate determination of albumin and globulin. Analyst, 56, 2-9; 73-8; 147-9; 228-35; January-April 1931.

Casein. The chemistry of casein and the state in which it exists in milk have been discussed in order to show the desirability of using an acid reagent for the purpose of its analytical separation. Experiments have been carried out which show that by mixing definite quantities of milk and a suitable acetic acid-sodium acetate buffer solution, a $p H$ close to the isoelectric point of casein can be obtained with cows' milk of widely varying composition. Even when the milk has soured somewhat, the effect of this on the final $p \mathrm{H}$ of the mixture is slight. Experiments have shown that in order to precipitate a maximum of casein from milk it is desirable to add the buffer solution in two parts, acid first, and then sodium acetate. When this is done the maximum

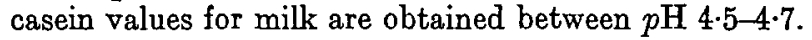

Upon the fundamental basis of the conception of the isoelectric point, it has been suggested that casein be defined as the material which is precipitated from cows' milk at $p \mathrm{H} 4 \cdot 6$, by acetic acid buffered by sodium acetate. Two methods have been used to show that casein precipitated in this way is chemically identical with the material precipitated at $p \mathrm{H} 4.2$ by acetic acid alone. (a) When the two caseins are digested with normal caustic soda at $37^{\circ} \mathrm{C}$., the production of amino groups as determined by the increase of the formol titration takes place at the same rate. (b) The rate of oxidation of the two caseins by sodium hypobromite under comparable conditions is the same for both.

Details of the proposed new method are as follows: Into a weighed covered beaker $(100-150 \mathrm{ml}$.) pipette $10 \mathrm{ml}$. of the well mixed sample, and weigh again quickly. Dilute with at least $50 \mathrm{ml}$. of water which has first been warmed to $40-42^{\circ} \mathrm{C}$. Add at once $1.5 \mathrm{ml}$. of $1.67 \mathrm{~N}$ (10 per cent.) acetic acid, and then stir very gently. After allowing to stand about 20 minutes, add $4.5 \mathrm{ml}$. of $0.25 \mathrm{~N}$ sodium acetate solution, and after stirring gently leave for at least an hour. Filter through a $9 \mathrm{~cm}$. No. 42 Whatman filter (fluted folding), and at once wash the precipitate three times by decantation. During two further washings break up the precipitate and transfer to 
the paper, and finally rinse the rim of the paper with a fine jet of water. Without delay clean out the beaker two or three times by adding water and successive portions of the sulphuric acid required for the Kjeldahl digestion, taking care to remove all the casein from the lip of the beaker and the stirring rod. Sundry explanatory notes are added and directions given (Paper 1) for treating milks of other animals besides the cow. The result should be expressed as per cent. of casein nitrogen.

Albumin and globulin. A study of previous work, supplemented by the writer's experiments, show that for the combined determination of these proteins the heatcoagulation method gives quite low results, while those obtained by the use of tannic acid are slightly high. Consequently the following method is tentatively proposed. To the filtrate obtained after the isoelectric precipitation of the casein sufficient trichloroacetic acid is added to make the final concentration approximately 4 per cent. The mixture is heated for half an hour on the boiling water bath, and after standing to cool, it is filtered and washed with a 1 per cent. solution of trichloroacetic acid. The nitrogen content of the precipitate is estimated by Kjeldahl's method. The separate determination of albumin and globulin is a very difficult problem which ought not to be attempted without consulting the literature cited in this paper.

G. M. Morr

P. ARUP. The analysis and composition of vegetable parchment used for packing dairy products. Analyst, 56, 660, 149-61, March 1931.

Forty-one samples of vegetable parchment and two of grease-proof paper were analysed for moisture, ash, water-soluble material and reducing material. Bursting strengths, wet and dry, and ability to support mould growth were also investigated. Tentative standards are suggested, namely: moisture, maximum, 10 per cent.; ash, 0.45 per cent.; water soluble extract, 1.3 per cent.; bursting strength, minimum, $25 \mathrm{lb}$. per square inch, for parchments of $25 \mathrm{lb}$. per ream and $18 \mathrm{lb}$. per square inch. for $18 \mathrm{lb}$. per ream. The strength after wetting should be at least a third of the dry strengths. The percentages of reducing material are given as a guide to the detection of added sugar. The reducing material was found to consist of degradation products of ligno-cellulose.

W. L. Davies

O. Warburg, F. Kubowitz and W. Christian. Ueber die katalytische Wirkung von Methylenblau in lebenden Zellen. (Catalytic action of methylene blue in living cells.) Biochem. Z. 227, iv-vi, 245-71, October 1930.

Methylene blue increases the oxygen consumption of blood cells by 20-30 times. Methhaemoglobin is first formed and is then reduced to haemoglobin quantitatively by the carbohydrate present. The methylene blue catalyses the oxidation of ferrous iron to ferric, which then catalyses the oxidation of the carbohydrate. In the absence of carbohydrate, methhaemoglobin accumulates.

J. G. Davis

M. A. B. Fixsen. The biological values of proteins. II. The biological value of purified caseinogen, and the influence of vitamin $B_{2}$ upon biological values, determined by the balance sheet method. Biochem. J. 24, iv, 1794-1804, 1930.

The biological value of purified caseinogen was redetermined by metabolism experiments on adult rats, and found to be 45 , a figure considerably lower than that of previous works. The technique was improved by supplying the B vitamins as concentrates containing only small amounts of nitrogen.

The absence of either vitamin $B_{1}$ or $B_{2}$ caused a decline of appetite within 48 hours; this was so great in the absence of $\mathrm{B}_{1}$ that the intake of calories was too low for reliable figures to be obtained for the calculation of biological values.

The absence of vitamin $B_{2}$ did not appear to prevent the economical use of ingested nitrogen, provided the calorie intake from fat and carbohydrate was adequate.

S. J. ROWLAND 
E. J. Quinn, J. G. Hartley and M. A. Derow. Some observations on the behaviour of vitamin A in or from primary sources. J. Biol. Chem. 89, ii, 657-63, December 1930.

The vitamin A in dry plant tissue is susceptible to destruction during storage. 70 per cent. loss in vitamin A occurred in dry spinach during 15 months storage. Addition of rancid fat to dry plant tissue caused a greater amount of destruction than in the dry material alone. Vegetable oils readily dissolve the vitamin from various types of plant tissue. Ultra-violet irradiation of petroleum ether extracts of carrot readily destroys vitamin A derived from this primary source.

W. L. Davies

\section{E. M. Hume and H. Henderson Smith. The value of foodstuffs for vitamin A.} Lancet, 1362-3, December 20, 1930.

The authors have estimated the vitamin A content of several foodstuffs using as a criterion the maintenance of rats depleted of their vitamin A reserves, over a set experimental period. They found that the minimal daily rat dose of spinach is $20 \mathrm{mg}$. or less, of cabbage more than 20 but less than $80 \mathrm{mg}$., of New Zealand butter $28 \mathrm{mg}$. or less. The corresponding dose of carotene is $0.003 \mathrm{mg}$. It is suggested that the evaluation of foodstuffs might be standardised against the value of a standard preparation of carotene.

S. K. KoN

H. A. Mattill. Anti-oxidants and the auto-oxidation of fats. J. Biol. Chem. 90, i, 141-51, January 1931.

This work was carried out to secure information as to the chemical nature of the anti-oxygenic substances found present in natural oils which prevent the auto-oxidative destruction of fat-soluble vitamins. The anti-oxygenic capacity of phenols resides in two hydroxyl groups being either in the ortho or para positions; when they are in the meta position the compound is inactive. The hydroxyl groups must also be directly attached to the nucleus. $\alpha$-naphthol is more effective than $\beta$-naphthol; while $\alpha$-naphthoquinone is inactive. Sterols of animal origin and sitosterol from plant sources were inactive. It is suggested that the existence of pro- and anti-oxygenic substances among the unsaponifiable constituents of natural fats may be concerned with the physiological action of the fat soluble vitamins.

W. L. Davies

M. J. Cummings and H. A. Matrill. The auto-oxidation of fats with reference to their destructive effects on vitamin E. J. Nutrition, 3, iv, 421-32, January 1931.

The auto-oxidisability of the fats, cod-liver oil, lard, butterfat, cottonseed oil, stearin, and hydrogenated cottonseed oil, was determined by measuring the induction period of oxygen absorption, and this susceptibility to oxidation was correlated with the reproductive behaviour of rats, fed on food mixtures containing these fats. The mixture of butter and hydrogenated cottonseed oil was most satisfactory while the mixtures, lard, cod-liver oil, and stearin butter were least successful. The efficiency of a given source of vitamin $\mathrm{E}$ depends in part on the auto-oxidisable materials and the anti-oxygens associated with it. The part played by vitamin $\mathrm{E}$ itself as an antioxygen is discussed.

W. L. Davies

B. Sure. Dietary requirements for fertility and lactation. I. The role of fat soluble

vitamins in fertility and lactation. Arkansas Agr. Exp. Sta. Bull. 250, June 1930.

In this and the following two bulletins the author assembles and summarises his published researches, begun in 1919, which have appeared in scientific periodicals. In the first bulletin lack of fertility or significant success in rearing of young on skimmed milk powder rations is discussed and is attributed to a dietary factor other than protein, the fat soluble vitamin A, the antirachitic vitamin or the water-soluble vitamin. Evidence is presented showing that the ethereal extracts of yellow maize, 
wheat embryo, and hemp seed contain a hitherto unrecognised organic factor which is essential for reproduction. The factor was also present in commercial cottonseed oil and commercial olive oil, but absent from commercial coconut, linseed or sesame oils. The requirement of vitamin B for normal mammary gland function is much greater than that for growth. The name vitamin $\mathrm{E}$ has been suggested by the author for the reproductive factor. Vitamin $E$ deficiency in the female albino rat is characterised by resorption of the foetus during gestation. The hypothesis is advanced that vitamin $\mathrm{E}$ may be composed of two fat soluble vitamins one essential for fertility, and another indispensable for lactation. Cod-liver oil as employed in the laboratory of the author has been demonstrated to be deficient in vitamin $\mathrm{E}$. When administered in excessive amounts to animals receiving a purified synthetic diet containing 5 per cent. Harris yeast, the same oil had a toxic effect on growing animals especially after mating. Butterfat was a much less potent source of vitamin $\mathrm{E}$ than wheat germ oil, but when introduced to the extent of 10 per cent. in a synthetic diet causing sterility it assured not only continuous fertility but also a noticeable success in lactation.

Vitamin B is one of the limiting factors, from the point of view of lactation, of various skimmed milk powder and whole milk powder diets studied.

Sterility characterised by resorption of the foetus during gestation and associated with vitamin A deficiency has been produced in rats on skimmed milk powder diet containing an abundance of vitamin E. Later work does not lend support to the dual theory of vitamin $\mathrm{E}$ previously advanced by the author, vitamin $\mathrm{E}$ must be considered exclusively as an antisterility vitamin. At the end of the bulletin the historical aspect of the discovery of vitamin $E$ and the work of other investigators are discussed.

S. K. KoN

B. Sure. Dietary requirements for fertility and lactation. II. The role of vitamin B in lactation and vitamin requirements of nursing young. Arkansas Agr. Exp. Sta. Bull. 251, June 1930.

A cold 75 per cent. ethyl alcoholic extract of $6.5 \mathrm{~g}$. of whole wheat embryo per animal per day furnished enough vitamin B for excellent growth. It was necessary, however, to supply the same alcoholic extract of at least $22.4 \mathrm{~g}$. of wheat germ per lactating rat per day to furnish sufficient vitamin B for normal lactation. A cold 25 per cent. ethyl alcoholic extract of approximately $13.0 \mathrm{~g}$. of the same wheat embryo per nursing animal per day furnished sufficient vitamin $\mathbf{B}$ for normal rearing and weaning of young.

The requirements of vitamin $B$ for normal mammary gland function were found considerably greater than that for optimum growth.

A quantitive biological method for the study of vitamin $B$ requirement for normal lactation has been described. By such a method it became apparent that yeasts from various sources vary considerably in their biological value as a source of vitamin $B$ for lactation. It was found that a concentrated preparation from yeast, prepared by releasing vitamin B from a yeast extract adsorbed on fuller's earth with sodium hydroxide, was three times as potent for normal lactation as the Harris yeast secured from the Harris Laboratories, Tuckahoe, New York.

By removing the daily yeast dosage (as a source of vitamin B) from the lactating mother during the latter part of lactation, when the nursing young are failing or when they show prolonged maintenance, rearing of the young was expedited and infant mortality at the same time circumvented. Upon applying the same technique with yeast concentrates, it was discovered that the lactating mother dissipates at least 60 per cent., if not more, of the vitamin B dosage daily apportioned to it in the metabolism of transfer to the milk.

To avoid infant mortality, nursing young need large amounts even of highly concentrated products of vitamin B daily during lactation. 
The large requirements of vitamin $B$ for lactation can now be explained as due to the inability of the nursing mother to secrete vitamin B quantitatively in the milk.

Accelerated growth of nursing young can be obtained by administration of liberal quantities of potent concentrated preparation of vitamin $B$.

A quantitative biological method has been perfected for the vitamin $B$ requirements of nursing young of the albino rat, which method is sensitive to the extent of $1 \mathrm{mg}$. per nursling per day.

A vitamin $B$ unit, applied to nursing young, has been defined as follows: the vitamin $B$ unit is the daily amount of vitamin B which must become available to a nursing young of the albino rat, weighing $30 \mathrm{~g}$., in order to permit a gain of $10 \mathrm{~g}$. in 7 to 10 days.

$1 \mathrm{~g}$. of a dehydrated baker's yeast "Federal" brand, has been found to contain 7 units of vitamin B. By applying the quantitative biological method of assay to vitamin $B$ concentrates, variations were found to the extent that $1 \mathrm{~g}$. contained as little as 14.4 units, and as much as 125 units.

Nursing young of the albino rat need approximately 100 times as much of the vitamin B complex (calculated in terms of dehydrated baker's yeast), as vitamins A and D (as furnished by a brand of cod-liver oil employed in the laboratory since 1921) for continuous growth during the nursing period.

Copper was found to have no supplementary value to a vitamin B concentrate for lactation.

A differentiation was made of the vitamin $B$ complex in rice polishings as evidenced in studies of lactation.

The lactating rat is unable to secrete quantitatively in the milk the antineuritic as well as the antipellagric factor, both of which are essential for growth.

Rice polishings contain, in addition to large amounts of the antineuritic factor for lactation, appreciable amounts of the antipellagric factor for growth.

Biological technique has been described for the production of uncomplicated vitamin $\mathbf{B}$ deficiency in nursing young of the albino rat.

Author's Summary

B. Sure. Dietary requirements for fertility and lactation. III. Pathological changes

in nursing young of the albino rat suffering from vitamin B deficiency, and the

role of vitamin B in infant nutrition. Arkansas Agr. Exp. Sta. Bull. 252, June 1930.

Nursing young of the albino rat suffering from a deficiency of vitamin B complex were found to die with accompanying hemorrhages in the osteogenetic tissues. Hemorrhages were also found in certain of the viscera.

Polyneuritic nursing young were found usually to die with their stomachs well distended with curd. The diets on which beriberi or polyneuritis were produced in the nursing young proved entirely satisfactory for maternal welfare and for the growth of non-lactating individuals.

Nursing young of the albino rat suffering from uncomplicated vitamin B deficiency develop marked hypoglycemia at a stage of the avitaminosis before loss of body weight has occurred. In such avitaminosis nursing young also develop anhydremia and marked disturbance in hematopoietic function. Vitamin therapy produces a rapid increase in concentration of blood sugar, and a regeneration of blood in polyneuritic nursing young of the albino rat.

Nursing young of the albino rat suffering from a deficiency of the vitamin B complex develop anhydremia, as is evidenced from hemoglobin determinations, erythrocyte counts, determinations of total blood solids, and studies of the refractive index of the blood serum. Such young also show marked disturbances in the hematopoietic function.

The lactating rat, whose nursing young are suffering from uncomplicated vitamin B deficiency, shows a normal range of concentration of alkaline reserve of the blood. 
Uncomplicated vitamin B deficiency in nursing young of the albino rat, during the stage of prolonged maintenance and incipient polyneuritis, bas no influence on the concentration of alkaline reserve of the blood. A reduction in concentration is noted only in the terminal stages of the disease, indicating acidosis.

The most noteworthy biochemical change in nursing young of the albino rat suffering from uncomplicated vitamin B deficiency is the marked reduction in the glycogen content of the liver.

A summary of the role of vitamin B in infant nutrition has been presented.

Author's Summary

H. O. Smith and V. E. Nelson. Cod-liver oil for reproduction and lactation. Proc.

Soc. Exp. Biol. Med. 28, iv, 393, January 1931.

Various samples of cod-liver oil were tested for their potency in the reproductive vitamin by introducing them into a standard ration and assessing the potency on the number of young produced per female per month with a "growing" ration as control. The oils were found to vary in vitamin $E$ content and to contain less than some natural foods. Ability to support the young was the basis of assessing the lactation-encouraging potency and mortality of the young varied with the kind of oil and the level of feeding. Mortality of pregnant females bore no relation to the potency of the oil in vitamin $\mathrm{E}$.

W. L. Davies

L. J. Peet, P. M. Nelson and E. H. Smith. Meat in nutrition. II. Some dietary factors influencing lactation. J. Nutrition, 3, iii, 313-23, November 1930.

Reproduction and lactation responses in albino rats fed on a balanced ration containing pressure-cooked lean beef as the main source of protein, were observed through three generations. Dietary modifications were added during the latter part of pregnancy and throughout lactation. Mothers on increased meat diet plus 15 per cent. yeast weaned the largest percentages of young in the three generations; but for the first two generations mothers on basal diet with autoclaved yeast addition reared an even larger percentage. Growth response in the young was greatest for the increased meat plus yeast diet. Increasing the meat protein of the diet tended to delay the onset of pregnancy.

W. L. Davies

E. W AтсноRN. Irradiated ergosterol and calcium-free diet: effect on calcium and phosphorus metabolism. Biochem. J. 24, v, 1560-3, 1930.

Calcium and phosphorus retention in rats on Steenbock's rachitogenic diet (2965) modified to contain $49 \mathrm{mg}$. of calcium and $60 \mathrm{mg}$. of phosphorus per $10 \mathrm{~g}$. of diet is decreased by excessive doses ( 0.05 per cent. of the diet) of irradiated ergosterol. The rats lost weight rapidly. On a similar diet, but containing $121.7 \mathrm{mg}$. phosphorus for $10 \mathrm{~g}$. of food and only traces of calcium, the same level of irradiated ergosterol does not effect the phosphorus metabolism, but causes elimination of calcium by the kidney. The calcium is probably lost from the bones or tissues. The animals continued to gain weight.

S. K. KoN

E. WATchoRN. The absorption and excretion of calcium and phosphorus by rats receiving excessive doses of irradiated ergosterol. Biochem. J. 24, iii, 631-40, 1930.

Calcium and phosphorus retention in rats is decreased by excessive doses of irradiated ergosterol fed in addition to a synthetic diet of caseinogen, rice, starch, arachis oil and salt mixture. The urinary calcium is greatly increased but not the phosphorus. The faecal content of both calcium and phosphorus decreases but not always in proportion to the intake. Even greater disturbances in retention and absorption occur during the recovery period after the administration of the irradiated 
ergosterol has been discontinued. The low food intake and loss of weight characteristic of the hyper-vitaminosis probably contribute to some of these results. The deposits of calcium found in certain tissues as the results of large doses of irradiated ergosterol cannot be accounted for on the grounds of increased absorption and retention. They are probably derived from the bones.

S. K. KoN

B. Sjollema and L. SEekLes. Ueber Störungen des mineralen Regulationsmechanismus bei Krankheiten des Rindes (Ein Beitrag zur Tetaniefrage). (Impairment of the mineral regulatory mechanism in diseases of cattle (A contribution to the problem of tetany).) Biochem. Z. 229, iv-vi, 358-80, December 1930.

Magnesium, ionised $\mathrm{Ca}$, diffusible $\mathrm{Ca}$, total calcium and inorganic phosphorus were estimated in the blood serum and in the ultra-filtrate from blood serum of normal cattle and of cows suffering from milk fever and grass staggers. The following average figures were obtained:

\begin{tabular}{|c|c|c|c|c|c|c|c|c|c|}
\hline & \multirow{2}{*}{$\begin{array}{l}\text { Aver. } \\
\text { of }\end{array}$} & \multicolumn{3}{|c|}{$\begin{array}{l}\text { Blood serum } \\
\text { Mg./100 c.c. }\end{array}$} & \multirow{2}{*}{$\begin{array}{c}\text { Aver. } \\
\text { of }\end{array}$} & \multirow{2}{*}{$\begin{array}{c}\text { Diff. } \\
\mathrm{Ca}\end{array}$} & \multicolumn{3}{|c|}{$\begin{array}{l}\text { Ultra filtrate } \\
\text { Mg./100 c.c. }\end{array}$} \\
\hline & & $\mathrm{Ca}$ & $\mathrm{Mg}$ & $\vec{P}$ & & & $\overparen{\mathrm{Ca}++}$ & $\mathrm{Mg}$ & $\mathrm{P}$ \\
\hline $\begin{array}{l}\text { ormal } \\
\text { filk fever } \\
\text { rass staggers }\end{array}$ & $\begin{array}{l}12 \\
25 \\
55\end{array}$ & $\begin{array}{l}9 \cdot 35 \\
4 \cdot 35 \\
6 \cdot 65\end{array}$ & $\begin{array}{l}1.66 \\
2 \cdot 19 \\
0.455\end{array}$ & $\begin{array}{l}4 \cdot 57 \\
2 \cdot 16 \\
4 \cdot 33\end{array}$ & $\begin{array}{l}12 \\
10 \\
18\end{array}$ & $\begin{array}{l}5 \cdot 23 \\
2 \cdot 36 \\
4 \cdot 19\end{array}$ & $\begin{array}{l}1.65 \\
0.44 \\
1.09\end{array}$ & $\frac{1.24}{0.27}$ & \\
\hline
\end{tabular}

The authors are inclined to link up the decrease of the $\mathrm{Ca} / \mathrm{Mg}$ ration in milk fever (2) and increase in grass staggers (14.6) as compared with the normal (5.6) with corresponding change in excitability accompanying the two diseases.

In grass staggers the serum magnesium was always low at the onset of a tetanic seizure but relatively high afterwards. The percentage of diffusible calcium was much more variable in milk fever and grass staggers than under normal conditions.

It is believed that a toxin either present in, or formed from the fodder is responsible for grass staggers.

S. K. KoN

M. G. Bertrand and Y. Brandt-Beauzemont. Sur la teneur en zinc du foie chez

le rat en voie de croissance. (Zinc content of the liver of the growing rat.) $A n n$.

Inst. Pasteur, 46, จ, 572-3, May 1931.

Previous investigations of the zinc content of animals at various stages of growth have been repeated on the livers of rats. Values obtained at the age of $1,15,30$ and 210 days were, 114, 5l, 37 and $34 \mathrm{mg}$. per cent. of dry weight, thus confirming previous work on whole animals which showed a similar fall, due to the low zinc content of milk.

The behaviour of this element resembles that of iron as shown by Bunge.

J. G. Davis

H. J. W ARTh and N. K. Ayyar. The influence of foodstuffs on the acid-base balance of cattle urines. Biochem. J. 24, iv, 1595-1600, 1930.

This paper describes a method for the determination of the acid-base balance of the cattle urine, based on a potentiometric titration of the urine freed from $\mathrm{CO}_{2}$ and figures for chlorides, sulphates, ammonia and hippuric acid.

Details are given of the results obtained at Bangalore by the application of this method to urines from green fodders, over ripe grasses and cereal straws, covering several varieties for each of these types. Marked differences in composition and reaction are recorded.

S. J. ROWLAND

M. Steuber and A. Seifert. Lactose in the economics of the growing organism. Arch. Kinderheilk. 85, 12-23, 1928. (Chem. Abst. 24, xx, 5057, October 20, 1930.)

A synthesis of fat from lactose, on a fat-free diet was not demonstrated. In the infant, lactose is not a suitable biological substitute for fat. 
S. S. MoCosh, I. G. MACY and H. A. Hunscher. Human milk studies. VI. Vitamin potency as influenced by supplementing the maternal diet with yeast. $J . B i o l$. Chem. 90, i, 1-13, January 1931.

The vitamin B content of the breast milk from three women was determined by rat experiments, before and after supplementing the usual maternal diets with $10 \mathrm{~g}$. yeast daily. The vitamin B content was found to be inversely proportional to the volume of milk secreted daily. The yeast-supplemented diet transferred into the milk a substance capable of making the experimental animals utilise their food more economically without augmenting food consumption.

W. L. Davies

W. E. KraUs and F. C. Mourve. A comparison of the influence of iodised mills and of potassium iodide administered directly, on the size and iodine content of the thyroid gland of rats. J. Biol. Chem. 89, ii, 581-8, December 1930.

The iodine content of milk may vary from a trace up to several parts per million depending on regional influences, and feeding cows with iodised mineral mixtures tends to make milk contain more than its normal content of iodine. Such "iodised milk" and samples of milk to which equivalent amounts of iodine as potassium iodide were added, on comparison with normal milk fed to white rats, were found to produce smaller thyroid glands of higher iodine content. For therapeutic and prophylactic purposes it is considered that direct addition of iodine to milk is more economical and controllable than the feeding of iodine-containing rations to cows. A short discussion on the advantages and disadvantages of an iodised milk supply is included.

W. L. Davies

S. J. ErLer and K. J. Pawlowsky. Der Stickstoffwechsel beim Saugkalb mit Milchfütterung. (The nitrogen metabolism of milk fed calves.) Biochem. Z. 228, i-iii, 89-100, November 1930.

The different forms of nitrogenous excretory products found in the wine of suckling calves varied but slightly from day to day. The urine was alkaline, containing but a trace of uric acid, a constant amount of creatine (creatine coefficient 20.33) and a considerable amount of hippuric acid. The ammonia content was low. The urea nitrogen decreased with age for calves of the same breed.

W. L. Davies

D. L. Drabkin and H. K. Miller. Haemoglobin production. II. The relief of anaemia, due to milk diet, by feeding amino acids. J. Biol. Chem. 90, ii, 531-43, February 1931.

Milk anaemia in rats was relieved by the addition of amino acids to milk containing an insufficient quantity of iron. The amino acids, arginine, glutamic acid and their salts proved effective for haemoglobin regeneration. Tryptophane, pyrrolidonecarboxylic acid, sodium aspartate and a proline mixture produced an initial increase in haemoglobin and remained at the higher level except in the case of sodium aspartate where severe anaemia again set in. Alanine and histidine and their salts produced no relief. With increase in haemoglobin, growth steadily took place after the stunting effect of anaemia.

W. L. Davies

R. Stenhouse Williams and E. C. V. Mattick. The importance of a complete study of the nutritional value of milk. J. State Med. 39, iii, 141-56, March 1931.

This is the report of a lecture given at the Royal Institute of Public Health. The authors dealt particularly with some of the known effects of heating milk upon the vitamin content, the proteins, ferments and salts, and with the results of feeding experiments which had been carried out upon the nutritional value of milk, when fed to school children and babies. They pointed out the necessity for further work along these lines, particularly for determining whether the nutritive value of milk was impaired by heating.

E. C. V. Mattick 
R. HEss. The treatment of rickets with irradiated mill. Strahlentherapie, 34, 787-97. (Chem. Abst. 24, xxii, 5806, November 20, 1930.)

Hess reports the results of experiments with milk irradiated with the Scheidt apparatus or with the Hanau quartz lamp in $\mathrm{CO}_{2}$. Ultracina or Vigantol were used for comparative purposes. Röntgen pictures and clinical findings served as the criteria. Fresh milk irradiated with the Scheidt apparatus gave positive results in about 30 per cent. of the cases; considerably more favourable results were obtained with the Hanau apparatus. The reasons for this uncertainty are shown. The treatment of rickets with irradiated milk is believed to deserve further attention. More favourable results are expected with an improved apparatus.

\section{G. LeIGHTON and P. L. MCKINLAY. Milk consumption and the growth of school children. Report on an investigation in Lanarkshire Schools. Edinburgh: H.M.S.O. 1930, pp. 20.}

This report gives the results of an extensive 4 months' experiment carried out in Lanarkshire schools to test the influence of the addition of $\frac{3}{4}$ pint of milk daily to the diet of children between the ages of 5 and 12 years. 5000 children received raw Grade A (T.T.) milk, 5000 received similar milk after pasteurisation, and 10,000 children were measured as controls.

The authors conclude that the milk produced a definite increase in growth, but that they found nothing to support the belief that younger children derived more benefit than older ones. Also that raw and pasteurised milk was so far as they could judge, equal in growth promotion.

Some of the results are shown in the following tables:

Average increase in weights (in ounces) in the three groups.

\begin{tabular}{|c|c|c|c|c|c|c|}
\hline \multirow[b]{2}{*}{ Age } & \multicolumn{3}{|c|}{ Boys } & \multicolumn{3}{|c|}{ Girls } \\
\hline & Control & Raw milk & $\begin{array}{l}\text { Pasteurised } \\
\text { milk }\end{array}$ & Control & Raw milk & $\begin{array}{l}\text { Pasteurised } \\
\text { milk }\end{array}$ \\
\hline $\begin{array}{c}5- \\
6- \\
7- \\
8- \\
9- \\
10- \\
11-\end{array}$ & $\begin{array}{r}11 \cdot 64 \\
13 \cdot 75 \\
11 \cdot 17 \\
11 \cdot 38 \\
9.53 \\
7 \cdot 10 \\
6 \cdot 14\end{array}$ & $\begin{array}{l}14.88 \\
13.51 \\
14.85 \\
14.21 \\
13.43 \\
13.53 \\
12.74\end{array}$ & $\begin{array}{r}15 \cdot 65 \\
9 \cdot 96 \\
15 \cdot 55 \\
15 \cdot 21 \\
11 \cdot 83 \\
10 \cdot 39 \\
11.05\end{array}$ & $\begin{array}{r}7 \cdot 00 \\
11 \cdot 21 \\
8 \cdot 90 \\
9 \cdot 77 \\
7 \cdot 87 \\
9 \cdot 51 \\
12 \cdot 62\end{array}$ & $\begin{array}{l}14.50 \\
10 \cdot 61 \\
11.22 \\
13 \cdot 40 \\
13 \cdot 81 \\
15 \cdot 08 \\
24.92\end{array}$ & $\begin{array}{r}6.62 \\
10.05 \\
12.94 \\
13.37 \\
12.52 \\
18.96 \\
17.08\end{array}$ \\
\hline $\begin{array}{l}\text { Average } \\
\text { of all ages }\end{array}$ & 10.06 & $13 \cdot 78$ & $12 \cdot 42$ & $9 \cdot 74$ & $14 \cdot 41$ & 13.82 \\
\hline
\end{tabular}

Average increase in heights (in inches) in three groups.

$\begin{array}{ccccccc}\text { Age } & \overbrace{\text { Control }}^{\text {Raw milk }} & \begin{array}{c}\text { Pasteurised } \\ \text { milk }\end{array} & \overbrace{\text { Control }} & \text { Raw milk } & \begin{array}{c}\text { Pasteurised } \\ \text { milk }\end{array} \\ 5- & 0.75 & 0.95 & 0.94 & 0.86 & 0.64 & 0.87 \\ 6- & 0.80 & 0.87 & 0.87 & 0.80 & 0.86 & 0.84 \\ 7- & 0.76 & 0.87 & 0.82 & 0.75 & 0.84 & 0.81 \\ 8- & 0.74 & 0.82 & 0.79 & 0.71 & 0.81 & 0.78 \\ 9- & 0.69 & 0.80 & 0.74 & 0.66 & 0.76 & 0.78 \\ 10- & 0.68 & 0.76 & 0.68 & 0.71 & 0.79 & 0.72 \\ \text { 11- } & 0.69 & 0.74 & 0.70 & 0.77 & 0.86 & 0.81 \\ \begin{array}{c}\text { Average } \\ \text { of all ages }\end{array} & 0.728 & 0.814 & 0.772 & 0.730 & 0.814 & 0.790\end{array}$




\begin{tabular}{|c|c|c|c|c|}
\hline \multirow[b]{3}{*}{ Age } & \multicolumn{4}{|c|}{$\begin{array}{c}\text { Differences of changes of weight and height in raw and } \\
\text { pasteurised milk-fed groups*. }\end{array}$} \\
\hline & \multicolumn{2}{|c|}{ Weight } & \multicolumn{2}{|c|}{ Height } \\
\hline & Boys & Girls & Boys & Girls \\
\hline $\begin{array}{c}5- \\
6- \\
7- \\
8- \\
9- \\
10- \\
11-\end{array}$ & $\begin{array}{r}-0.77 \pm 3 \cdot 19 \\
3 \cdot 55 \pm 0.94 \\
-0.70 \pm 1.08 \\
-1 \cdot 00 \pm 1.00 \\
1 \cdot 60 \pm 0.98 \\
3 \cdot 14 \pm 1 \cdot 24 \\
1 \cdot 69 \pm 1.44\end{array}$ & $\begin{array}{r}7 \cdot 88 \pm 4.02 \\
0.56 \pm 0.94 \\
-1.72 \pm 1.04 \\
0.03 \pm 1 \cdot 00 \\
1.29 \pm 1 \cdot 12 \\
-3.88 \pm 1 \cdot 28 \\
7.84 \pm 1 \cdot 68\end{array}$ & $\begin{array}{l}0.01 \pm 0 \cdot 075 \\
0.00 \pm 0 \cdot 018 \\
0.05 \pm 0.019 \\
0.03 \pm 0.018 \\
0.06 \pm 0.017 \\
0.08 \pm 0.019 \\
0.04 \pm 0.021\end{array}$ & $\begin{array}{r}-0.23 \pm 0.055 \\
0.02 \pm 0.015 \\
0.03 \pm 0.019 \\
0.03 \pm 0.017 \\
-0.02 \pm 0.016 \\
0.07 \pm 0.018 \\
0.05 \pm 0.026\end{array}$ \\
\hline $\begin{array}{l}\text { Average } \\
\text { of all ages }\end{array}$ & $1 \cdot 30$ & 0.42 & 0.044 & 0.026 \\
\hline
\end{tabular}

[In criticism of the experiment it may be pointed out that in selecting the children a system of random choice was used but not adhered to, also only one kind of milk was used in one school so that direct comparison between the kinds of milk is less reliable than if both milks were used in all schools. Again while there can be no doubt that the milk diet increased growth very considerably, it is not difficult to show that the conclusion drawn by the authors as to equality in the growth value of raw and pasteurised milk is statistically unsound. In actual fact the results show a significant advantage in favour of raw milk.]

S. BARTLETT

M. V. K. NELSON. The growth and nitrogen metabolism of infants receiving undiluted milk. Amer. J. Dis. Child. 39, 701-10, 1930. (Physiol. Abst. 15, x, 587, January 1931.)

In nine healthy infants the total nitrogen retention, the retention per kilogram, and the percentage of intake retained were greater on undiluted milk than when they received diluted milk and therefore less food. There was an increased rate of growth in both weight and length.

F. Kolbe. Vigantol und bestrahlte Milch. (Vigantol and irradiated milk.) Z. $f$. Fleisch- $u$. Milchhyg. 41, iii, 47-9, November 1, 1930.

A review with forty-seven references, of the German work on the antirachitic value of irradiated ergosterol and irradiated milk.

S. K. KoN

H. TAYLOR. Haematopoietic properties of dried milk. Lancet, No. 5593, 1041, November 8, 1930.

This letter draws attention to the work of Mackay, which had been neglected by Bacharach in his article on the subject.

G. L. PesketT

J. E. BeCker and E. V. McCollum. Dietary deficiencies of milk. Aner. J. Hyg. 12, ii, 503, September 1930 .

The authors employed a basal diet consisting of whole milk powder (Klim) and dextrinised starch. By varying the level of dextrinised starch many substances were added to the basal diet. Of 38 diets in which milk powder was used at a $60-85$ per cent. level in combination with other substances, 24 sufficed for production of young. In 4 cases fifth generations have been obtained; the supplements in these diets were cooked dried beef liver 4 and 5 per cent. (60 per cent. of whole milk powder), yeast 5 per cent. (60 per cent. dried milk powder) and a combination of ferric citrate $(0.5$ per cent.) and copper sulphate ( 0.1 per cent.) ( 70 per cent. whole milk powder). The authors think that it is the richness of liver in iron and copper that makes it an effective supplement to milk.

S. K. KoN 
RoEmmele and STöHR. Ueber den Einfluss eines mit d-Vitamin durchsetzten Futters auf die Milch. (Influence on milk of fodder enriched with vitamin D.) Milchw. Forsch. 10, v-vi, 413-23, October 1930.

$100 \mathrm{~g}$. of maize flour containing 1 c.c. of a solution of vitamin D (potency not stated) in oil were added daily for 6 weeks to the normal diet of four milch cows. This amount was increased to $1000 \mathrm{~g}$. daily (containing 10 c.c. of the solution of vitamin D) for a subsequent period of 8 days. Four control cows received during similar periods equal amounts of maize flour from which the vitamin D solution was omitted. The milk from the two groups was compared and no difference was found in the vitamin $D$ content, the percentage of fat, the calcium content, the milk yield, the melting point of the fat and in the suitability for cheese making.

[Steenbock, Hart, Hanning and Humphrey (J. Biol. Chem. 88, i, 197-213, August 1930) have recently shown that the antirachitic potency of milk can be increased by feeding milch cows $50 \mathrm{~g}$. of irradiated yeast daily (equivalent to 50,000 Steenbock rat units of vitamin D), but that the milk yield and fat content of the milk are not affected. It is difficult to appraise the value of the negative findings of Roemmele and Stöhr concerning the vitamin $\mathrm{D}$ content of the milk from their experimental cows, as the antirachitic potency of the preparation fed is not stated.] S. K. KoN

W. Scheimpflug. Vergleichende Untersuchungen über antirachitische Wirkung von nach Scholl und nach Hoffmann bestrahlter Milch an Ratten. (Comparative investigations on the antirachitic action on rats of milk irradiated by the Scholl and Hoffmann methods.) Milchw. Forsch. 10, v-vi, 455-80, October 1930.

Rats rendered rachitic by feeding the rachitogenic diet of Pappenheim, McKann and Zucker were cured by the daily administration of 1 c.c. of milk irradiated with ultra-violet light by the method of Scholl. Milk irradiated by the Hoffmann method was ineffective at the same level and was undistinguishable from non-irradiated milk. The rennetability of the milk irradiated by the method of Scholl was increased by 30-70 per cent. when compared with unheated milk or with milk irradiated by the method of Hoffmann. It was found that the Scholl lamp had an ultra violet intensity 5700 times greater than that of the Hoffmann lamp.

S. K. KoN

M. E. F. Crawford, J. Golding, E. O. V. Perry and S. S. Zilva. The fat-soluble vitamins of milk. Biochem. J. 24, iii, 682-91, 1930.

Vitamins $A$ and $D$ were determined in whole milk, in butter churned from the cream separated from the original milk, and in the skim milk $(0.1$ per cent. fat $)$ to which the buttermilk was added in equivalent quantities. The whole milk, skim milk, and buttermilk had been dried under reduced pressure at a temperature never above $36^{\circ} \mathrm{C}$. The growth obtained with skim milk plus buttermilk was proportional to the amount of residual fat present in the doses the animals received, and agreed with the growth of those receiving butter containing corresponding amounts of butterfat. The growth with whole milk was proportional to the milkfat content of the doses. The results suggested that the entire vitamin $A$ and vitamin $D$ content of whole milk and skim milk is associated with the milk fat, and that there is no significant loss of either vitamin due to separating or churning.

S. J. ROWLAND

H. Hentschel and O. Bachmans. Determination of total sterol and ergosterol in cow's milk. Comparative values for milk of different origin. Z. ges. exp. Med. 71, 744-54. (Brit. Chem. Abst. A, p. 508, April 1931.)

Potassium hydroxide is added to milk, and the fat extracted with ether; after saponification, the unsaponifiable fraction is extracted with ether and treated with digitonin solution. The factor is 0.2431 . The following sterol contents of milk (mg. 
per litre) are recorded: Rosenheim 77, Allgäu 57, Berlin 60, Central Germany 101. Corresponding values for inactive ergosterol were: $0 \cdot 19,0 \cdot 13,0 \cdot 10,-$. The spectrum of the fourth sample suggested the presence of activated ergosterol.

W. WeItzel. Die Vitamine der Milch und ihr Verhalten chemischen, physikalischen und thermischen Einflüssen gegenüber. (Vitamins of milk and their reaction to chemical, physical and thermic influences.) Münch. tierärztl. Wochr. 81, 104-7, 1930. (Zbl.f. Bakt. I, Ref. 99, xxi-xxii, 527, November 1930.)

H. WIeland and T. F. Macrae. Mechanism of oxidation processes. XXVI. Dehydrogenating enzymes of milk. Annalen, 483, 217-250, 1930. (Brit. Chem. Abst. A, p. 389, March 1931.)

On keeping or by agitation, the power of milk samples to promote the oxidation of xanthine by methylene blue is increased. This is explained by the fact that the union of the fat droplets causes a decrease of the surface on which the xanthine dehydrogenase is probably absorbed. The aldehyde dehydrogenase shows less marked increase in activity on keeping or by agitation. The conclusion is reached that the xanthine and aldehyde dehydrogenases are separate enzymes. Removal of xanthine dehydrogenase from whey can be effected by absorption on calcium carbonate leaving the aldehyde dehydrogenase in solution in a less active form. Hydrogen peroxide inhibits aldehyde oxidation in the presence of methylene blue. The enzyme solutions are able to effect the dismutation of aldehyde (aromatic and aliphatic) into acid and alcohol (optimum $p H$ 8.3). The same enzyme is responsible for the aerobic and anaerobic oxidation in the presence of methylene blue and for the dismutation. The effect of cyanide on the three reactions is of the same order of activity.

W. L. Davies

\section{S. SASARI. Ueber die serologische Differenzierung der Milch- und Serum-Eiweiss-} körper. (Milk and serum Proteins.) Arb. Med. Univ. Okayama, 1, 550-81, 1930. (Physiol. Abst. 15, 10, January 1931.)

Milk globulin and serum globulin are identical proteins which are formed in the maternal blood stream. Casein is first formed in the milk. Milk albumin and serum albumin are different from one another. Milk albumin as well as casein is first formed in the mammary gland. There is a 100: 40 relationship between the proteins of cow's and goat's milk. This relationship is approximately the same for the casein, albumin and globulin. The formation of the antibodies for the individual proteins is more or less divergent. The formation of that for casein is the most rapid, and in proportion that for albumin the slowest. The specificity of heated casein was confirmed by the precipitin method. Casein is the only heat-stable protein, the others being all heat labile.

\section{J. Zayowsky and P. AllksejefF. Die Katalase der Milch. I. Die Bestimmung der} Milchkatalase mit $\mathrm{KMnO}_{4}$-Titration. (The catalase of milk. I. The estimation of catalase in milk by permanganate titration.) Fermentforsch. 12, i, 55-66, 1930.

The usual methods of determining catalase in milk by actual measurement of oxygen liberated from hydrogen peroxide have the disadvantage of not being able to demonstrate fine differences and of giving varying results in duplicates. A finer method whereby the undecomposed peroxide is determined by permanganate titration, is described. Two ml. milk and $98 \mathrm{ml}$. water, $5 \mathrm{ml} .0 .3$ per cent. $\mathrm{H}_{2} \mathrm{O}_{2}$ and $5 \mathrm{ml}$. 10 per cent. $\mathrm{H}_{2} \mathrm{SO}_{4}$ are mixed together. A control mixture containing $2 \mathrm{ml}$. of boiled milk is also made. After allowing to stand 30 minutes at room temperature, the excess peroxide is determined by titration with standard decinormal permanganate. This 
method gives a more accurate value for the number of milligrams of oxygen liberated from hydrogen peroxide by $100 \mathrm{ml}$. of milk, but the values are of the same order as those found by Henkit's and Lobeck's methods.

W. L. Davies

R. A. Morton and I. M. Heilbron. Vitamin A of butter. Biochem. J. 24, iv, 870-3, 1930.

As the physiological action of the vitamin A of liver oils can be closely simulated by the plant pigment carotene, the non-saponifiable matter from butter was examined spectroscopically for vitamin $A$ and carotene. It was shown to contain both of them, and their potency estimated with some degree of accuracy.

S. J. Rowland

\section{PHYSIOLOGY.}

J. H. NoRRIs. A chemical investigation in Victoria (Australia) of the blood of cattle and sheep. Austr. J. Exp. Biol. and Med. 7, iii-iv, 1930. (Physiol. Abst. 16, i, 21, April 1931.)

For steers the average total phosphorus content of the blood in mg. per 100 c.c. was found to be 10.13 , for cows 12.59 . The average iron content in $\mathrm{mg}$. per 100 c.c. was 60.54 for steers and 57.92 for cows.

A. Westerlund. A contribution to the lmowledge of calcium metabolism. III. The relative faecal outgo of calcium in dairy cows. Slkand. Arch. Physiol. 60, 251-63, 1930. (Chem. Abst. 25, iv, 735, February 20, 1931.)

A statistical study of the co-variations of the factors affecting the relative $\mathrm{Ca}$ elimination points to the conclusion that the difficulty of keeping lactating cows in $\mathrm{Ca}$ equilibrium on the usual feeds is chiefly due to the unsuitability of such controlling factors as the scanty supply of some dietary constituents necessary to guarantee the animal's maximum utilisation of the $\mathrm{Ca}$, i.e. Ca itself, as well as $\mathrm{P}$, fat, Na and silage, while such constituents as $\mathrm{Mg}$ or $\mathrm{Si}$ are supplied too abundantly in proportion to the $\mathrm{Ca}$ consumed. Besides, the milk secretion is also of importance, the more copious its flow the smaller the relative faecal outgo of $\mathrm{Ca}$.

J. Watrin and P. Florentin. Tumeur utérine et sécrétion lactée chez la lapine. (Uterine tumour and lactic secretion in the doe rabbit.) C.R. Soc. Biol. 104, xxvi, 1286-8, September 20, 1930.

The authors made a complete examination of a doe rabbit in which abundant milk secretion occurred without pregnancy. They found a uterine tumour which had been caused by retention of the maternal placenta from the previous pregnancy, but none of the foetal placenta; a development of the interstitial tissue of the ovaries which showed no corpora lutea, and other changes (in thyroid and adrenals), which are normally associated with pregnancy. They therefore exclude the foetus, ovary or corpus luteum as the cause of milk secretion and conclude that it was due to the presence of uterine deciduoma in the maternal organism. The authors discuss the possible mode of action of the deciduoma.

G. L. PesketT

G. W. CoRner. The hormonal control of lactation. I. Non-effect of the corpus luteum.

II. Positive action of extracts of the hypophysis. Amer. J. Physiol. 95, 43-55, 1930. (Physiol. Abst. 15, xi, 667, February 1931.)

The mammary gland of non-pregnant spayed rabbits could not be made to proliferate beyond the normal pubertal degree of the development by either the administration of corpus luteum extract or by experimental production of continuous 
corpora lutea in the ovaries. But whole sheep's hypophysis given to spayed virgin rabbits did cause the proliferation of the mammary gland and lactation resembling a full-term gestation. No previous sensitisation by corpus luteum was necessary.

H. H. Cole. A study of the mucosa of the genital tract of the cow, with special reference to cyclic changes. Amer. J. Anat. 46, 261-302, 1930. (Physiol. Abst. 15, xi, 668, February 1931.)

The character of the vaginal epithelium normally alters in passing from the vestibule to the cervix. Changes are traced in the vestibule, vagina and cervix from prooestrum to post-oestrum. In the vagina proper during the pro-oestrum the surface epithelium consists of large, wide, mucus-secreting cells beneath which are two or three layers of polyhedral epithelial cells. At the time of heat the surface cells are tall and columnar, and the underlying layer is reduced to one or two layers. At 2 days post-oestrum the vaginal epithelium is restored to several layers, and the surface layer is only slightly differentiated from the underlying layers. At 10 days postoestrum the epithelium is vacuolated and somewhat degenerate. The stroma becomes oedematous during pro-oestrum and oestrum, and the blood vessels are congested. Changes in the cervix closely resemble those in the vagina.

O. LaxA. Retained milk. Ann. Falsificat. 23, 609-10, 1930. (Analyst, 56, 660, 184, March 1931.)

Twelve cows in the month of August travelled by rail for 3 days, and were not milked until they arrived at the farm, and four of these then only yielded about 100 c.c. of milk. This milk resembled colostrum, and was white with a brown tint, and had a smell of burnt milk, attributed to the decomposition of the milk sugar. The milk contained water, 78.4 ; fat, 10.15 ; casein, 2.65 ; albumin and globulin, 0.0 ; albumoses and peptones, 2.92 ; amino acids, 1.78; milk sugar, 1.50 ; ash, 1.10; and undetermined substances 1.50 per cent.

J. McFadyean. The corpora amylacea of the mammary gland of the cow. J. Comp. Path. and Therap. 43, iv, 291-300, December 1930.

The paper opens with a summary of the more important articles that have already appeared on the subject. These have shown that amyloid bodies occur very commonly in the udders of cows, but that there is no evidence to suggest that they are constantly present. Most of the bodies are not composed of the same material throughout, though all have a stratified structure. The use of the adjective amyloid seems unjustifiable, as no part of them gives the characteristic reactions with methyl violet, or iodine.

The author inclines to the view that the majority of the bodies are formed $a b$ initio free in the alveoli from a central portion, which has basophil-staining reactions and is not stratified. Stratification occurs by accretion of materials from the surrounding fluid, the cells of the alveoli do not necessarily play any part in the formation of the bodies. The need for further research work is emphasised. G. L. Pesketr

G. N. Porovski. Effect of milk feeding on secretion of gastric juice. Russ. $J$. Physiol. 12, 331-47, 1930. (Brit. Chem. Abst. A, p. 1466, November 1930.)

From experiments with dogs with a stomach pouch it is concluded that milk contains a substance stimulating the secretory activity of the gastric glands. The substance is thermostabile, and is soluble in 96 per cent. alcohol, water, and ether, but not in absolute alcohol. 
S. V. TeLfer. Mineral metabolism in infancy. II. Utilisation of mineral elements in human milk. Glasgow Med. J. 33, 10-20, 1930. (Brit. Chem. Abst. A, p. 1615, December 1930.)

All of the elements are retained by the infant in the proportion in which they are present in the milk, the retention being approximately 60 per cent. of the intake.

\section{DAIRY HUSBANDRY.}

Feeding value of cottonseed hulls as a roughage for growing dairy heifers. The use of cottonseed meal and hulls as a ration for lactating cows. Texas Sta. Rpt. p. 857, 1929. (Exp. Sta. Record, 63, v, 472, October 1930.)

The average score of 24 heifers fed cane hay was $80.67 \pm 1.01$ per cent. in November and for 17 head of the same heifers $76.41 \pm 1.45$ per cent. in June. The corresponding scores for heifers fed cottonseed hulls were $77.00 \pm 1.12$ per cent. (22 head) and $72.24 \pm 1.91$ per cent. (17 head).

No material differences in the general bealth and condition of the udders of the cows in this test were observed that could be attributed to differences in the rations. Observations on fertility and reproduction did not show that the feeding of cottonseed meal, even in excess, had any significant effects as compared with a balanced ration. Cottonseed meal had no apparent constipating effect as judged by the consistency of the faeces.

E. EDIN and G. SundeLIN. Undersökningar angaende fodermärgkal, dess odling och odlingsvärde. (Investigations on marrow stem kale, its cultivation and feeding value.) Sweden Cent. Agric. Exp. Sta. Medd. 376, 1930.

Very useful information on marrow stem kale is supplied in this report, which contains a four page English summary. The notes include the composition, results of digestibility trials and some helpful details regarding the use of the crop for stock feeding.

The average composition of the organic matter was found to be: crude protein 16.4 per cent., fat 3.1 per cent., fibre 18.5 per cent., $N$-free extract 62.0 per cent. (true protein 10.9 per cent.).

The average digestibility as determined by the chromium oxide indicator was as foilows:

\begin{tabular}{lcc} 
& \multicolumn{2}{c}{$\begin{array}{c}\text { Fresh but last } \\
\text { harvest's } \\
\text { kale }\end{array}$} \\
Crude protein & 75 & Dried kale \\
Fat & 66 & 68 \\
Fibre & 48 & 25 \\
N-free extract & 88 & 53 \\
Carbohydrates & 81 & 77 \\
Organic matter & 78 & 70 \\
True protein & 67 & 66 \\
True protein with & 83 & 53 \\
pepsin HCl & & 67
\end{tabular}

S. BARTLETT

W. B. Ellet, C. W. Holdaway, J. F. Eheart and L. D. Lasting. Feeding hevea rubber-seed meal for milk production. Virginia Agric. Exp. Sta. Tech. Bull. No. 41, April 1930.

Hevea rubber-seed meal is a new high protein concentrate in the United States. It is the by-product from the kernels of the seed of the Para rubber tree (Hevea brasiliensis) after the extraction of the oil. The by-product comes as cake from the 
pulp presses and when ground forms a dry, friable and rather fine meal having a pleasant odour. Experiments with this meal have been conducted with dairy cows to determine its value for milk production and the digestibility of its constituents.

The results indicate that Hevea rubber-seed meal may be used as a medium protein concentrate in rations for cows. It is palatable, neither laxative nor constipating in its physiological effect on the digestive system and is apparently equal to linseed meal (equivalent to English linseed cake or cake meal) for milk production. Up to $5 \mathrm{lb}$. per head daily may be given. The analysis and digestibility coefficients (in brackets) were as follows: moisture, 9 per cent.; crude protein, 27.5 per cent. (71); ether extract, $9 \cdot 5$ per cent. (92); crude fibre, $15 \cdot 0$ per cent. (20); nitrogen-free extract, 33.5 per cent. (58); ash, 5.4 per cent.

J. MackintosH

0. E. REed and C. F. Huffman. The results of a five-year mineral feeding investigation with dairy cattle. Michigan Agric. Exp. Sta. Tech. Bull. No. 105, February 1930.

In this experiment the effects of a basal ration low in minerals (especially calcium), of mineral supplements in the form of bone flour, limestone rock (finely ground), raw rock phosphate (finely ground), and a complex mineral mixture and of alfalfa hay in place of timothy hay, were studied. Seven lots of five heifers (all Holstein Friesians of similar age and breeding) were used and maintained under this experiment from the age of 6 months to 5 years. Data were obtained on the rate of growth, reproduction, health of cows and calves, milk and fat yields and the effect of the various supplements on appetite and on the bones and teeth. Numerous illustrations of the cows at various ages and of their calves are given and interesting information is supplied on the rate of growth, breeding records, etc.

The results indicate that the general need for mineral supplements for dairy cattle under normal conditions may be greatly exaggerated. Mineral supplements supplying calcium are not greatly needed even when such feeds as timothy hay and other low calcium roughages are used. Raw rock phosphate to the extent of 1.5 per cent. of the grain mixture injured the health and teeth of the animals perhaps by reason of its fluorine content, also the complex mineral mixture used, in the course of time caused harmful effects and injury to the teeth.

J. Mackintosh

\section{K. W. D. CAMPBELL. Milking at three eight-hour intervals as a means of investigating}

variations in the fat and solids-not-fat. J. Agric. Sci. 20, ii, 213-32, April 1930.

The object of this investigation was to collect evidence on the effect of thricedaily milking on the yield of individual cows, and on the effect of milking at three eight-hour intervals on the percentage and weight of butterfat. Twelve cows in the herd at the University of Reading Farm were milked thrice daily, at the hours of 6 a.m., 2 p.m. and 10 p.m. throughout a complete lactation; at each milking the milk yielded by each cow was weighed, sampled and the percentages of fat and solids-notfat determined. The cows were all home-bred Dairy Shorthorns which calved between November 29, 1927, and May 3, 1928, and of different ages, viz. 1st calf 3; 2nd calf $3 ; 3$ rd calf $2 ; 4$ th calf 2 , and 5 th calf 2 . The management was on uniform lines throughout the period.

It was found that the nine cows increased in milk yield when milked thrice daily by an average of 19.3 per cent., the individual yields showing a range of from a decrease of $21 \cdot 1$ per cent. to an increase of 41.8 per cent. The calculated increase obtained from the three first-calf heifers was 5.6 per cent. These comparisons are made on the milk yields after standardisation by the methods suggested by Sanders. The effects of intervals of varying length between the milkings on the milk yield and percentage of fat is discussed. Tables are given showing the variation in milk yield and fat percentage from day to day. The author suggests that some factor operates at 
night tending to lower the rate of fat secretion and that this factor operates whether the night interval be long or short.

[No reference is made in the text to the solids-not-fat content of the milk, and the possibility of the variations in milk yield and fat content being due to changes in the milkers or in the efficiency of milking is not considered.]

J. Mackintosh

R. E. Glover. Tuberculin testing of graded herds of cows. Brit. J. Tub. 24, 75-8, 1930. (Bull. Hyg. 5, xi, 883, November 1930.)

Two tuberculin tests are discussed, i.e. the subcutaneous, and the double intradermal. The advantages and defects of the subcutaneous test are discussed, particularly the desensitisation which may result when the animals are tested at periodical intervals. The factor has led to so-called tubercle free herds not being always free from tuberculosis although all were non-reactors. The double intradermal method, after a period of 5 years' testing has been shown to be much superior to the old method, while it is not followed by desensitisation. The second inoculation after the preliminary sensitising dose is a most important modification, as from 5 to 40 per cent. of reacting animals produce either a negative or doubtful reaction with the first dose. Tuberculins of known potency must be used.

\section{DAIRY INDUSTRY.}

United States of America-White House Conference on Child Health and Protection. Report of committee on milk production and control. U.S.A. Public. Health Rep. 46, xiv, 769-811, April 3, 1931.

The report is divided into four parts dealing with: (1) Communicable diseases transmitted through milk; (2) Public health supervision of milk; (3) Nutritional aspects of milk; (4) Economic aspects of milk. Each part has been prepared by a special sub-committee.

(1) Milk-borne epidemics of diphtheria, dysentery, gastroenteritis, paratyphoid, poliomyelitis, scarlet fever, septic sore throat, typhoid fever and undulant fever reported in the U.S.A. during the six years 1924-9 are tabulated and discussed. A special table sets forth the sources of milk infection. The following recommendations are made: I. That pasteurisation be required whenever practicable. II. That pasteurisation is not intended to take the place of the sanitary production of clean and wholesome milk, but rather to provide the final factor of safety from milk-borne diseases. III. That co-operative effort between producers, control and educational officials gives promise of the best and most lasting results.

(2) The following points are discussed: (a) The essential elements of the Public Health supervision of milk supplies which include inspection of farms and plants, supervision of the physical examination and testing of cows, laboratory examination of milk, physical examination of workers and residents at farms and plants including laboratory examination of body discharges and pasteurisation control of general market milk. (b) The fundamental items which should be included in the laws and regulations relating to the Public Health supervision of milk supplies and the agencies which should enforce them. (c) The evaluation of the results of the enforcement of laws and regulations. (d) The present status of the Public Health supervision of milk supplies in the U.S.A. (e) Recommendations for the White House Conference with reference to future improvements of the supervision of milk supplies in the U.S.A.

(3) The various constituents of milk are enumerated and discussed and recommendations for future research work on milk are made. They include a study of the toughness of the curd formed by rennet coagulation of the vitamins and inorganic 
constituents of milk, of the biological value of milk proteins, of the value of different kinds of milk in infant feeding and of the optimal proportion of milk in the diet of infants and children. Further work on colostrum, a detailed study of human milk, and standardisation of equipment for pasteurising milk and researches on the chemistry of casein and the nutritional value of whey and whey powder are considered necessary. The increased production of milk powders, evaporated milk and condensed milk is advocated for reasons of economy.

(4) The following points are discussed: (a) The consumption of fluid milk and cream. (b) The consumption of other milk products. (c) The production of milk. (d) The marketing of milk. (e) The transportation, processing and delivery. ( $f$ ) The sanitary quality of milk and cream, and suggestions relating to these points are made.

S. K. KoN

F. A. Clark. Results of the operation of the standard milk ordinance in Missouri. Pub. Health Rep. 46, xxiv, 1413-24, June 12, 1931.

W. Barton. Graded milk movement in Scotland. Scottish Farmer, 39, No. 1983, 80-1, January 17, 1931.

J. F. Blackshaw and R. Stenhouse Williams. La production du lait propre en Angleterre. (Clean milk production in England.) Paper at Comm. d'Étude Fédération Int. Laiterie, 1930. J. Agric. Belgique, 12, xlv, 353-4, November 8, 1930; xlvi, 365-6, November 15, 1930; xlvii, 371-2, November 22, 1930; xlviii, 381-2, November 29, 1930.

J. BERKo. A tej megitelese reduktase es erjesztöproba utjan nyert vizsgalati adatok, valamint sorozatosan vegzett savokmeghataroz sok alapjan. (Judging milk on the basis of reductase, fermentation and acidity tests.) Mezogazd. Kutat. 2, ix, 417-21, 1929. (Biol. Abst. 4, xi, 2746, November 1930.)

In comparison of the keeping quality of dairy milk and of gathered farmers' milk the reductase and fermentation tests showed that the methods of production and therefore the keeping quality of the dairy milk are much better than those of gathered farm milk. The dairy milk boiled without coagulation after 7 hours, this was not true of the farmers' milk after 2 hours.

K. Diernhofer. Untersuchungen über den Geschmacksfehler der "schmirgeligen Milch." (Faulty flavour of "emery" tainted milk.) Milchw. Forsch. 10, v-vi, 319-35, October 1930.

A taint resembling a metallic emery taste can be produced in milk by inoculation with an anaerobic organism of the Fraenkel bacillus type. This organism can be isolated from commercial samples of milk which possess the emery taint. The taint originates from the breakdown of oleic acid and not from butyric fermentation, the development being catalysed by the presence of copper and iron salts in traces. An attempt was made to determine the substance responsible for the taint.

W. L. Davies

H. BaRKWORTH. The influence of the fat content on the keeping quality of milk. J. Min. Agric. 37, viii, 803-6, November 1930.

The opinion prevalent in the dairy industry that rich milk does not keep so well as milk of average quality has been studied by classifying 4002 samples of milk of which the bacterial content and keeping qualities were known, into three groupsviz. under 3.0 per cent., between 3.0 and 4.0 per cent. and over 4.0 per cent. It was found that the keeping qualities of all three classes were equally good where the bacterial count was low, but with counts of over 100,000 per c.c. there was a tendency 
for the samples with a fat content of over 4.0 per cent. to lose a little in keeping qualities as the count increased. The loss, as shown by this study, amounted to only 2-3 hours in the case of milk with a keeping quality of 42 to 48 hours, and is scarcely of commercial importance. (Had it been possible to include a sufficient number of samples containing 5 per cent. fat more useful information would have been obtained on the keeping qualities of rich milk.)

J. MaOKINTOSH

G. J. and A. M. Hucker. Commercially prepared infant foods. New York Bull. 584. October 1930.

This is a non-technical bulletin describing the various classes of commercial infant foods (reconstructed infant food, milk modifiers, protein milk, lactic acid milk, powdered, evaporated, and condensed milk). Every infant food should meet the following standards: I. It should be produced under clean conditions. II. There should be no harmful bacteria present. III. The number of bacteria present should be reduced to a minimum. Practically all of the infant foods on the market at the present time meet these standards.

S. K. KoN

L. A. Allen and J. BeLL. The role of milk constituents in bread making. J. Roy. Tech. Coll. Glasgow, 2, 550-63, 1931.

The paper briefly reviews some of the literature on this subject and mentions the beneficial results following beat treatment of milk or separated milk designed for use in bread making. "Grewe and Holm found that dried skim milk which had been preheated to $73,83,93$ or $100^{\circ} \mathrm{C}$. gave a decided improvement in loaf volume and fermentation tolerance as compared with milks preheated to $50^{\circ}$ or $63^{\circ} \mathrm{C} . "$

In their preliminary experimental work the authors attempted to compare the relative values of whole millk, separated milk, whey and whey from which the albumen had been precipitated; thus removing in turn the fat, the fat and casein, and lastly the fat, casein and albumen.

In these experiments five batches of $2 \mathrm{lb}$. loaves (four in each batch), were made in order to compare colour, texture, flavour, etc. The effect on the keeping quality and water content of the loaves does not appear to have been determined.

The baking formula selected was as follows: $4 \mathrm{lb}$. strong wheat flour, $1 \frac{1}{4} \mathrm{lb}$. soft winter wheat flour, $\frac{1}{2}$ oz. sugar, $\frac{1}{2}$ oz. lard, $1 \frac{1}{2}$ oz. salt, 2 oz. yeast and 1500 c.c. water. The fermentation period was 75 minutes, the proof period 30 minutes, and the time of baking 30 minutes.

The results were as follows:

Texture. Whole milk, separated milk and whey, first, protein free milk next, and control last.

Colour. Whole milk first, separated milk and whey second, control third, and protein free milk last.

Flavour. Whole milk, separated milk and whey first, followed by control bread, the protein free being put last.

The results were confirmed by a series of batches of $1 \mathrm{lb}$. loaves made on the same lines.

Much of the practical work was devoted to an estimation of the effect of milk constituents on the volume increase of fermenting dough.

The method consisted in measuring the increase in volume taking place in dough contained in a measuring cylinder which was placed in a water bath at a constant temperature. For this purpose a mixture of strong spring wheat flour 225 g., yeast $22.5 \mathrm{~g}$., salt $9 \mathrm{~g}$., water 250 c.c. was used. These constituents were first well mixed with a pestle and mortar and the mixture was then transferred to a mechanical whisk where it was agitated for exactly 120 seconds. A weighed quantity was transferred to a 500 c.c. measuring cylinder.

Jour. of Dairy Research II 
The cylinders were maintained at $29^{\circ} \mathrm{C}$. and the increase in volume noted which took place between the commencement of fermentation and the point where the risen dough broke and started to decrease in volume.

Four determinations were made with each type of milk or milk product and the average taken. It is claimed that this method gave more concordant results than the customary methods of determining the volume of the finished loaf. The extent to which the indirect method was a true index of the actual loaf volume is not stated owing to the difficulties experienced by the authors in recording small differences by the customary methods.

The effect of milk constituents on the rate of evolution of gas in fermenting dough was also determined. From this work the authors drew the following conclusions:

1. Addition of either whole milk, separated milk or whey to the dough used for bread making resulted in improved texture, colour and flavour in the finished loaf. As regards colour, whole milk was found to be superior to the other two products.

2. Experiments conducted with separated milk, whey, and whey from which the albumen had been extracted, respectively, in order to determine their influence on the volume increase in a fermenting dough, showed that separated milk had a slightly detrimental effect, whey had an appreciably detrimental effect, while whey minus albumen had an appreciably beneficial effect.

3. The theory that the albumen is a determining factor in volume increase was confirmed by some experiments made with a suspension of egg albumen, when it was found that the increase in a fermenting dough was smaller than that in a control dough containing no albumen.

4. Boiling the milk products for $\mathbf{1 5}$ minutes under reflux prior to their use in a dough mix was found to have a remarkably beneficial effect on the volume increase during fermentation. It is suggested that this is due to the coagulation of the albumen which normally exercises a softening influence on the gluten, thus decreasing its holding power. Even the coagulated albumen was found to have a small detrimental effect.

5. Dried separated milk prepared by the pressure spray system was found to decrease the volume of a fermenting dough, compared with a control dough containing no milk. If the milk was boiled prior to drying, however, this detrimental effect was largely counterbalanced. It is therefore important when using separated milk for bread making to choose a variety which has been preheated, so that the beneficial effect on the texture, flavour, colour and nutritional value may not be counterbalanced by a detrimental effect on the volume.

6. Lactose had no effect on the volume of the dough. Small quantities of lactic acid, on the other hand, resulted in a slight improvement.

7. Whey, boiled whey and whey minus albumen respectively were found to increase the rate of evolution of carbon dioxide from a fermenting dough, while separated milk, raw or boiled, decreased it. It is suggested that the phosphates in the milk tend to increase the rate of fermentation but that the casein has an inhibitory effect. Removal of the casein in the preparation of the whey allowed the beneficial effect of the phosphates full play. Albumen too, appears to have an appreciably damping effect on the fermentation.

8. Rennin was found to have no effect on the rate of fermentation of dough by yeast.

J. Golding 
C. C. WALTS and M. S. LIBBERT. Factors influencing the flavour of butter. I. The effect of various starter cultures on the flavour of butter. II. The effect of various neutralisers on the flavour of butter. Arkansas Agr. Exp. Sta. Bull. 249, February 1930.

I. Nine different commercial starter cultures were compared and only minute differences in the flavour produced were noted by the judges. At the same time control butter made without the addition of a starter scored only 0.49 to 2.3 per cent. less marks than the butter made with the addition of a commercial starter.

II. Eleven neutralising agents for the same cream were used in experimental butter making, but insufficient evidence was available to show that any one agent was better than the others.

E. C. G. MADDOCK

W. H. Udy. Mottled colour in cheese. N.Z. Jour. Agric. 42, iv, 244-5, April 1931.

This defect occurring mostly in hot weather, appears as a patchy discoloration approaching complete bleaching in some areas of the annatto colouring of New Zealand coloured cheese. Investigations revealed that the effect of direct sunlight falling on milk and curd in the vat was an important cause of the mottled colour. Five minutes' exposure of milk with annatto in a vat to direct sunlight caused appreciable surface bleaching and 30 minutes caused total bleaching. Sunlight acting through a few inches of whey or whey-soaked curd caused the same partial bleaching effect. Exposure of vats to direct sunlight was common, and mottling was most prevalent in cheese made in these vats. Methods of diffusing sunlight are suggested.

W. L. Davies

\section{P. S. LuCas, T. MatsUi and O. E. Moor. Influence of sugar and butterfat on the} quality of ice cream. Michigan Agric. Exp. Sta. 1930, Spec. Bull. 201. (Brit. Chem. Abst. B, 134, February 6, 1931.)

Increased fat content within the range 8-14 per cent. improved the flavour, body, texture, and resistance to melting of ice cream. Mixtures with the lower fat content became coarse on storage. Increasing milk solids-not-fat (6-12 per cent.), improved texture and increased the acidity without affecting resistance to melting. With more than 12 per cent. of solids-not-fat the mixtures were "sandy."

\section{REVIEW}

Ministry of Agriculture. Report on the marketing of dairy produce in England and Wales. Part I. Cheese. Min. Agric. Economic Series, No. 22.

In Part $I$, the outline of types and varieties of cheese is ably drawn. The cheesemaking areas are briefly sketched, and the origin of factory cheese making is discussed. This is followed by a chapter on supply, in which a diagram, setting out the average monthly imports of cheese over a five-year period reveals the remarkably small variation that exists owing to the fact that the exporting seasons from New Zealand and Canada, Great Britain's chief suppliers, only appreciably overlap in July and August. In the chapter on demand there is an interesting table showing the per capita consumption of cheese in various countries. Great Britain with $9.5 \mathrm{lb}$. per annum occupies a middle position between the extremes of Switzerland with $23 \cdot 3 \mathrm{lb}$. and Canada with only $3 \mathrm{lb}$. per head. The preparation for market, methods of marking and grading cheese are described in detail, and the efforts of the Cheshire and Cheddar cheese farmer producers to grade and mark their cheese receives special attention. A suggested scheme for a National Mark for all varieties of cheese is outlined and its early introduction foreshadowed. The illustrations are admirable, and there is a useful appendix of tabulated information.

E. CAPSTICK 


\section{STATISTICS}

\section{Number of Dairy and Other Cattle.}

ThE following table shows comparative figures of the dairy herd, and of other cattle, in the principal countries within the British Empire in which dairying is of major importance. The figures are in each case the latest available, and are generally of a preliminary nature, but it should be noted that the estimates of livestock relate to different dates in the various countries. It should also be noted that classification of cattle into the dairy herd and other cattle is not a matter of uniform practice throughout the Empire, but the figures give a fairly accurate indication of the extent of the dairy herd and of any change in comparison with the preceding census.

\begin{tabular}{|c|c|c|c|c|}
\hline Countries & Year* & $\begin{array}{l}\text { Cows and } \\
\text { heifers in } \\
\text { milk or } \\
\text { in calf }\end{array}$ & $\begin{array}{l}\text { Other } \\
\text { cattle }\end{array}$ & $\begin{array}{l}\text { Total } \\
\text { cattle }\end{array}$ \\
\hline England and Wales & $\begin{array}{l}1931 \\
1930\end{array}$ & $\begin{array}{c}000 \text { bead } \\
2790 \\
2715\end{array}$ & $\begin{array}{c}000 \text { head } \\
3274 \\
3135\end{array}$ & $\begin{array}{c}000 \text { head } \\
6,064 \\
5,850\end{array}$ \\
\hline Scotland & $\begin{array}{l}1931 \\
1930\end{array}$ & $\begin{array}{l}452 \\
453\end{array}$ & $\begin{array}{l}757 \\
783\end{array}$ & $\begin{array}{l}1,209 \\
1,236\end{array}$ \\
\hline Northern Irelsnd & $\begin{array}{l}1931 \\
1930\end{array}$ & $\begin{array}{l}259 \\
256\end{array}$ & $\begin{array}{l}421 \\
417\end{array}$ & $\begin{array}{l}680 \\
673\end{array}$ \\
\hline Irish Free State & $\begin{array}{l}1931 \\
1930\end{array}$ & $\begin{array}{l}1223 \\
1225\end{array}$ & $\begin{array}{l}2819 \\
2813\end{array}$ & $\begin{array}{l}4,042 \\
4,038\end{array}$ \\
\hline Canada & $\begin{array}{l}1930 \\
1929\end{array}$ & $\begin{array}{l}3683 \\
3685\end{array}$ & $\begin{array}{l}5254 \\
5140\end{array}$ & $\begin{array}{l}8,937 \\
8,825\end{array}$ \\
\hline Australia & $\begin{array}{l}1929-30 \\
1928-29\end{array}$ & $\begin{array}{l}\text { Not } \\
2467\end{array}$ & $\begin{array}{l}\text { iilable } \\
\qquad 8834\end{array}$ & $\begin{array}{l}11,202 \\
11,301\end{array}$ \\
\hline New Zealand & $\begin{array}{l}1930 \\
1929\end{array}$ & $\begin{array}{l}1424 \\
1371\end{array}$ & $\begin{array}{l}2297 \\
2075\end{array}$ & $\begin{array}{l}3,721 \\
3,446\end{array}$ \\
\hline Union of South Africa & $\begin{array}{l}1929 \\
1928\end{array}$ & \multicolumn{2}{|c|}{$\begin{array}{l}\text { Not available } \\
\text { Not available }\end{array}$} & $\begin{array}{l}10,518 \dagger \\
10,478\end{array}$ \\
\hline Kenya & $\begin{array}{l}1931 \\
1930\end{array}$ & $\begin{array}{l}71 \\
68\end{array}$ & $\begin{array}{l}166 \\
159\end{array}$ & $\begin{array}{l}237 \ddagger \\
227\end{array}$ \\
\hline
\end{tabular}

* Estimates relate to June except New Zealand (January 1), South Africa (August 31), Kenya (February 28, 1931 and July 31, 1930); for Australian States estimates refer to December 31 except New South Wales and F.C.T. (June 30 following).

$\dagger$ Including 6,773,000 cattle on farms owned by Europeans.

$\ddagger$ Relates solely to European owned cattle; the estimated number of native-owned cattle in Kenya was 4,966,000 on July 31, 1930. 


\section{Trade in Dairy Produce.}

The following tables give details of the trade in butter and cheese of the principal countries handling these products during the first 6 months of 1931 , with comparative figures for 1930. The particulars are based on information published by the International Institute of Agriculture, Rome, brought up to date, where necessary, from official sources.

Exports and imports of butter. Six months (January to June).

\begin{tabular}{|c|c|c|c|c|c|}
\hline \multirow{2}{*}{\multicolumn{2}{|c|}{ Countries }} & \multicolumn{2}{|c|}{ Exports } & \multicolumn{2}{|c|}{ Imports } \\
\hline & & 1931 & 1930 & 1931 & 1930 \\
\hline \multicolumn{2}{|l|}{ Exporting countries } & $000 \mathrm{lb}$. & $000 \mathrm{lb}$. & $000 \mathrm{lb}$. & $000 \mathrm{lb}$. \\
\hline Austria $\quad \ldots$ & $\ldots$ & 1,166 & 1,786 & 1,052 & 293 \\
\hline Denmark ... & $\ldots$ & 190,579 & 187,294 & 972 & 822 \\
\hline $\begin{array}{lll}\text { Estonia } & \ldots & \text {. }\end{array}$ & $\ldots$ & 12,436 & 11,378 & - & - \\
\hline Irish Free State. & ... & 12,573 & 19,703 & 3,148 & 2,754 \\
\hline Finland $\ldots$ & $\ldots$ & 21,433 & 22,051 & - & - \\
\hline Hungary ... & $\ldots$ & 701 & 1,561 & 112 & - \\
\hline Latvia $\quad \ldots$ & $\ldots$ & 16,945 & 17,655 & 18 & 24 \\
\hline Lithuania... & ... & 7,319 & 5,432 & - & - \\
\hline Netherlands & $\ldots$ & 39,699 & 47,792 & 2,718 & 1,636 \\
\hline Norway $\ldots$ & $\ldots$ & 1,093 & 229 & 79 & 267 \\
\hline Poland $\quad .$. & $\ldots$ & 11,903 & 10,278 & 20 & 11 \\
\hline Sweden $\ldots$ & $\ldots$ & 23,171 & 30,931 & 4 & 13 \\
\hline U.S.S.R. ... & $\ldots$ & 18,052 & 9,833 & - & - \\
\hline Argentina... & $\ldots$ & 28,444 & 25,743 & - & - \\
\hline India $\quad \ldots$ & $\ldots$ & 185 & 309 & 165 & 132 \\
\hline Syria and Lebanc & & 996 & 1,087 & 121 & 37 \\
\hline Australia ... & $\ldots$ & 93,981 & 57,367 & - & - \\
\hline New Zealand & $\ldots$ & 114,070 & 122,207 & - & 一 \\
\hline \multicolumn{6}{|l|}{ Importing countries } \\
\hline Belgium ... & $\ldots$ & 1,270 & 1,213 & 18,805 & 10,029 \\
\hline Czecho-Slovakia & & 302 & 448 & 2,200 & 293 \\
\hline France $\quad \ldots$ & $\ldots$ & 4,594 & 5,137 & 28,949 & 9,279 \\
\hline Germany ... & $\ldots$ & 143 & 348 & 102,586 & 129,890 \\
\hline Greece $\quad \ldots$ & $\ldots$ & - & - & $981^{*}$ & $765^{*}$ \\
\hline Italy & $\ldots$ & 1,045 & 1,323 & 4,405 & 1,283 \\
\hline Spain & $\ldots$ & 51 & 95 & 33 & 119 \\
\hline Switzerland & $\ldots$ & 4 & 24 & 12,207 & 9,264 \\
\hline United Kingdom & & 21,832 & 7,449 & 446,460 & 404,248 \\
\hline Canada ... & $\ldots$ & 2,366 & 399 & 2,813 & 32,710 \\
\hline U.S. America & $\ldots$ & 1,210 & 1,841 & 728 & 1,872 \\
\hline Ceylon $\quad \ldots$ & $\ldots$ & - & - & 322 & 401 \\
\hline Java and Madur & & - & - & 4,255 & 4,325 \\
\hline Japan $\quad \ldots$ & $\ldots$ & - & - & 128 & 406 \\
\hline Algeria $\ldots$ & $\ldots$ & $24 \dagger$ & $24 \dagger$ & $1,362 \dagger$ & $1,288 \dagger$ \\
\hline Egypt $\quad \ldots$ & $\ldots$ & 15 & 9 & 1,199 & 1,263 \\
\hline Tunis & $\ldots$ & 2 & 2 & 476 & 439 \\
\hline
\end{tabular}


Exports and imports of cheese. Six months (January to June).

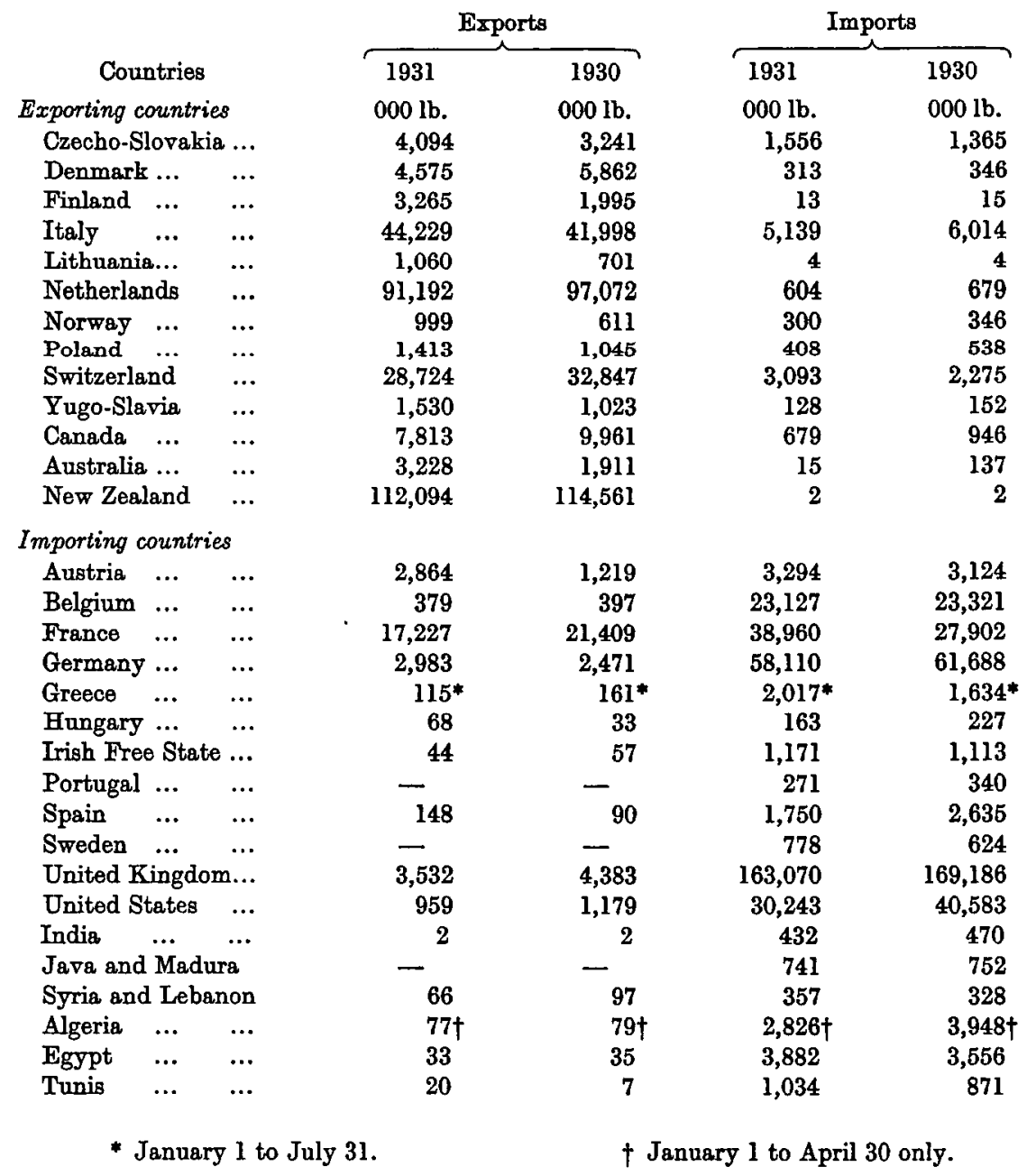

